\title{
Board of Governors of the Federal Reserve System
}

\author{
International Finance Discussion Papers
}

Number 759

February 2003

\section{Transmission of Information Across International Equity Markets Jon Wongswan}

NOTE: International Finance Discussion Papers are preliminary materials circulated to stimulate discussion and critical comment. References to International Finance Discussion Papers (other than an acknowledgment that the writer has had access to unpublished material) should be cleared with the author or authors. Recent IFDPs are available on the Web at www.federalreserve.gov/pubs/ifdp/. 


\title{
Transmission of Information Across International Equity Markets
}

\author{
Jon Wongswan*
}

\begin{abstract}
This paper provides evidence of transmission of information from the U.S. and Japan to Korean and Thai equity markets during the period from 1995 through 2000. Information is defined as important macroeconomic announcements in the U.S., Japan, Korea, and Thailand. Using high-frequency intraday data, I focus the study on return volatility and trading volume because the implications of new information are much clearer than for returns. I find a large and significant association between emerging-economy equity volatility and trading volume and developed-economy macroeconomic announcements at short-time horizons. This is the first strong evidence of this sort of international information transmission. Previous studies' findings of at most weak evidence may be due to their use of lower frequency data and their focus on developed-economy financial market innovations as the measure of information.
\end{abstract}

Keywords: information, volatility, trading volume, high-frequency data, macroeconomic announcements, dispersion of expectations

JEL classification: E44, G14, G15

\footnotetext{
* Division of International Finance, Board of Governors of the Federal Reserve System. I would like to thank John Ammer, Ravi Bansal, Tim Bollerslev, Mark Carey, Bjørn Eraker, Campbell Harvey, Pete Kyle, George Tauchen, and students in the Duke Econometrics and Finance Lunch Group for their suggestions. I thank Jon Faust, Thanomsri Fongarun-Rung, Duangporn Rodpengsangkaha, Kotaro Yoshida, and the staff at the Bank of Thailand for providing information on macroeconomic announcements and expectations. Of course, I take responsibility for any and all errors. For questions and comments, please contact Jon Wongswan. Email: Jon.Wongswan@frb.gov. The views in this paper are solely the responsibility of the author and should not be interpreted as reflecting the views of the Board of Governors of the Federal Reserve System or of any other person associated with the Federal Reserve System.
} 


\section{Introduction}

As world capital markets have become increasingly integrated, information originating from one market is likely to become more important to other markets. Understanding the transmission of information is crucial for asset valuation, risk sharing, and economic policy.

An extensive literature has explored the transmission of information across global financial markets, but only weak evidence of transmission from developed-economy equity markets to emerging-economy equity markets has been found (e.g., Bekaert and Harvey (1997) and Ng (2000)). ${ }^{1}$ This result is surprising because most emerging economies rely heavily on international trade, predominantly with developed economies (especially the U.S. and Japan). Table 1 shows that international trade relative to gross domestic product is large for several emerging economies. Information regarding macroeconomic fundamentals of developed economies should significantly influence emerging-economy fundamentals and thus emerging equity market returns and volatility. ${ }^{2}$

Existing evidence of information transmission to emerging markets may be weak because of the nature of the information that has been analyzed and because low-frequency data have been used. Existing studies have focused on transmission from one equity market to another, not directly on the impact of information about economic fundamentals. Information is typically defined as innovations from asset pricing models or as volatility changes and the focus is on the impact of innovations or volatility in one market on returns or volatility in another market. Measured information from a developed market is likely to be of varying importance for an emerging market. Thus, the impact of material information about fundamentals might be masked by information that may be important to the developed market but that is approximately noise for the emerging market. For example, Table 1 shows that the fraction

\footnotetext{
${ }^{1}$ Studies focusing on information transmission among developed markets are Eun and Shim (1989), Hamao, Masulis, and Ng (1990), Engle, Ito, and Lin (1990), Lin and Ito (1994), Karolyi (1995), and Karolyi and Stulz (1996). Studies focusing on transmission from developed markets (mainly the U.S. and Japan) to emerging markets are Cheung, He, and Ng (1994), Kim and Rogers (1995), Bekaert and Harvey (1997), and Ng (2000).

${ }^{2}$ During the 1970's through the mid-1980's, most emerging economies had restrictions on capital flows. However, this does not necessarily explain the weak financial linkages found by earlier papers because most emerging economies relied heavily on international trade, so information regarding a trading partner's economy should impact the domestic market even when there are capital controls.
} 
of emerging market volatility that can be explained by developed market volatilities is small.

Studies of transmission of information that use low-frequency data also may fail to capture short-run or mean-reverting dynamic effects. Recent research has shown that the properties of equity prices can be better captured with a two-factor stochastic volatility model that includes (1) a short-run or mean-reverting factor and (2) a long-run or persistence factor (e.g., Alizadeh, Brant, and Diebold (2002), Gallant, Hsu, and Tauchen (1999), Engle and Lee (1999), and Chernov, Gallant, Ghysels, and Tauchen (2001)). ${ }^{3}$ Moreover, it has been shown in the literature that the impact of information on volatility is short-lived (e.g., Ederington and Lee (1993), Andersen and Bollerslev (1998), Fleming and Remolona (1999), and Balduzzi, Elton, and Green (1999)). This may help explain why previous studies do not find evidence of information transmission from developed markets to emerging markets, as information primarily affects the short-run volatility factor, an effect masked by the low-frequency data.

This paper is the first to study international transmission of economic fundamental information using high-frequency data. I study information transmission from the U.S. and Japan to Korea and Thailand during 1995 through 2000. Information is defined as important macroeconomic announcements in the U.S., Japan, Korea and Thailand. Using minute-byminute intraday equity market data, macroeconomic announcements and expectation about such announcements, I investigate the impact of U.S. and Japanese macroeconomic announcements on intraday return volatility and trading volume for Korea and Thailand. ${ }^{4}$ I estimate two-factor stochastic models for volatility and trading volume in which the shortrun component is allowed to vary with information. Empirical measures of information are dummy variables for each announcement, the size of announcement surprises (measured as the absolute value of the difference between the actual announcement and the median

\footnotetext{
${ }^{3}$ Alternatively, many papers add a jump component to price dynamics (Pan, 1999; Jones, 1999; Eraker, Johannes, and Polson, 2000; Andersen, Benzoni, and Lund, 2001). It should be noted that both the two-factor model and one-factor model with a jump component imply observationally indistinguishable price dynamics. Which model is the correct specification remains an open question and is beyond the scope of this paper. However, I prefer the two-factor model because the impact of information on volatility persists for a short time as opposed to a single period.

${ }^{4} \mathrm{I}$ also control for macroeconomic announcements from Korea and Thailand.
} 
of analysts' expectations), and the dispersion of announcement expectations (measured as the cross-sectional standard deviation of all analysts' expectations for each announcement). With the ability to identify the sources of information, this paper avoids the problem of spurious relationships which could arise if we use financial market innovations to proxy for information. ${ }^{5}$

I find that macroeconomic announcements in U.S. Nonfarm Payrolls (EMPNF) and Japanese Industrial Production Index (IPI) induce large but short-lived increases in Thailand return volatility (on average they last about 30 minutes). However, the results on Korean market volatility vary across time. Prior to the end of 1998, Japanese Monetary Policy Meeting (MPM) decisions and Japanese IPI have a large but short-lived effect on volatility (on average they last about 30 minutes). After the end of 1998, only the announcement of the U.S. Consumer Price Index (CPI) has a large but short-lived effect on Korean return volatility. It should be noted that these U.S. macroeconomic announcements have been found to have a significantly short-lived burst of volatility effect on various U.S. financial markets (e.g., Ederington and Lee (1993) and Andersen and Bollerslev (1998)).

The paper also assesses the impact of transmission of fundamental information across international markets on intraday trading volume. ${ }^{6}$ I estimate a two-factor trading volume model in which the short-run trading volume component is allowed to vary with macroeconomic announcements. I find that announcements that affect Thailand's volatility (U.S. EMPNF and Japanese IPI) and U.S. Federal Open Market Committee (FOMC) decisions induce large and significant short-lived increases in trading volume for Thailand (on average they last about 45 minutes). As for the Korean market, the same announcements that affect its volatility (Japanese MPM and IPI) also have a large and significant short-lived

\footnotetext{
${ }^{5}$ To my knowledge, Connolly and Wang (2002) is the only paper which defines information as macroeconomic announcements that studies the transmission of information in an international context. This paper differs from Connolly and Wang (2002) in that 1) they use open and close prices to proxy for intraday movement; 2) they focus on returns which can be problematic as described further below; and 3) they study transmission among the U.S., U.K., and Japan.

${ }^{6}$ Several studies have examined the impact of information on trading volume within a single country (e.g., Li and Engle (1998), Fleming and Remolona (1999), and Balduzzi, Elton, and Green (1999)). To my knowledge, Lin and Ito (1994) is the only paper which studies the transmission of information across international equity market on trading volume. They based the study on daily data.
} 
increases in trading volume (on average they last about 45 minutes). An examination of trading volume is helpful because it sheds light on the details of reactions to information that is not revealed by examining return volatility alone. Some macroeconomic announcements are expected by an average market participant (implying no measured announcement surprises), but the expectations of individual market participants may be dispersed. When announcements are made, uncertainty is resolved and individuals may rebalance portfolios, with the volume of rebalancing positively related to the dispersion of expectations. This idea is consistent with theoretical models put forwarded by Karpoff (1986), Kim and Verrecchia (1991), Shalen (1993), and Harris and Raviv (1993). I find a strong positive empirical relationship between the dispersion of expectations about U.S. EMPNF, the FOMC decisions, and Japan IPI and post-announcement trading volume.

Although short-lived effects on volatility and volume are not themselves of great economic importance, such effects are indirect evidence of an impact of international information transmission on returns, which might be quite important economically. Unfortunately, direct examination of the impact of announcements on returns cannot provide convincing evidence in an international context because the sign of the impact surprise is unpredictable. Announcements affect a variety of economic variables, including trade flows, capital flows, and exchange rates, and the net implication of any given announcement for emerging-economy equity returns can differ with circumstances. Thus, any of a negative, zero, or positive unconditional average reaction of returns to announcements could be consistent or inconsistent with economically important international financial linkages. ${ }^{7}$ Conditioning on circumstances would require taking a position about the details of a structural international macroeconomic model and such models remain in flux at this time.

In contrast, the effects of announcements on volatility and volume are predictable, which motivates this paper's empirical focus. Although it is logically possible that substantial volume effects could occur even if announcements have only a small impact on returns, it seems more likely that agents trade more in the wake of announcements because asset

\footnotetext{
${ }^{7}$ I estimated the impact of announcements on return processes for my sample and cannot reject the hypothesis of a zero impact.
} 
prices are finding a new level. Moreover, because volatility is measured as absolute return deviation, the finding of significant volatility is also a finding that prices move significantly in response to information. Thus, I regard this paper as providing the first evidence of substantial information transmission from developed economies to emerging-economy equity markets.

The remainder of the paper is organized as follows. Section 2 describes data sources and presents summary statistics. In section 3, preliminary results are discussed. The model and estimation method are described in section 4. Section 5 presents empirical results. Finally, section 6 concludes and discusses directions for future research.

\section{Data Description}

\subsection{Equity Market Data}

The intraday minute-by-minute Korea total market index and volume are from the Korea Stock Exchange and cover the period from January 3, 1995, through December 26, 2000. During this period the Korea Stock Exchange operates under four different sets of trading hours. I labelled each period as Subsample I, II, III, and IV (see Figure 1). The intraday minute-by-minute Thailand total market index and volume are from the Stock Exchange of Thailand and cover the period from January 3, 1995, through December 29, 2000. The trading hours are shown in Figure 1.

In order to mitigate the nonsynchronous trading problem for component securities in an index (Lo and MacKinlay (1990)), I compute return, both for Korea and Thailand, at fifteen-minute intervals. ${ }^{8}$ To minimize the stale prices problem, the opening prices are taken after the market has been open for fifteen minutes. The first return of each day is computed from yesterday's closing price and today's opening price. Volatility is measured as absolute return deviation: $\left|R_{t, n}-\bar{R}_{t, n}\right|$, where $R_{t, n}$ is return for interval $n$ in day $t$ and $\bar{R}_{t, n}$ is the

\footnotetext{
${ }^{8}$ The criterion in selecting the return interval is to find the interval that has the lowest average intraday return autocorrelation. I compare autocorrelations for one-minute, five-minute, ten-minute, fifteen-minute, twenty-minute, and thirty-minute periods. Results are available on request.
} 
expected return for interval $n$ in day $t$. The expected return is computed as sample averages of return across all days, $t$, for a given time interval, $n$. Trading volume is computed as the number of shares traded over any fifteen-minute interval.

As it is often encountered in high-frequency data, I removed days when returns and trading volume are contaminated by recording errors. These errors often occur as either sequences of zeros in the total market market index and trading volume or sequences of negative values in trading volume. I removed days when the sequences are longer than an hour. With these criterions, I removed 23 days from Korea and 3 days from Thailand.

Table 2 provides basic statistics summary. The average fifteen-minute returns are all insignificantly different from zero except for Thailand. The average intraday return autocorrelation, even at the fifteen-minute interval which has the lowest autocorrelations, is all significant except in the case of Korea Subsample I. As for volume, it is very highly correlated. Figure 2 and 3 plot intraday return, volatility, and volume of Korea Subsample I and Thailand, respectively. ${ }^{9}$ The dashed line represents a two-standard deviation band. Intraday returns do not exhibit any pattern; however, intraday volatilities exhibit a U-shape similar to patterns documented in other markets (Andersen and Bollerslev $(1997,1998)$ and Ito, Lyons, and Melvin (1998)). ${ }^{10}$ The spike in the middle of the day is due to high activity when market reopens after the lunch-time break. The sharp decreases of Korean market's volatility and volume in the last trading period are due to batch auction in the last ten minutes used for computing closing prices. During this batch auction period, there is no trade. Intraday volume and volatility exhibit similar patterns which is also similar to what has been documented in the literature for U.S. equity markets (Tauchen and Pitts (1983), Karpoff (1987), and Foster and Viswanathan (1993)).

It is worth pointing out that, due to the time differences between the U.S. and Asia, the impact of U.S. announcements would appear on the first trading period of the following day. This delay might lead to a problem in differentiating the impact of U.S. information

\footnotetext{
${ }^{9}$ To conserve space, I only report results for Korea Subsample I. Results for Korea other subsamples are qualitatively similar and are available on request.

${ }^{10}$ See theoretical explanation in Admati and Pfleiderer (1988) and Foster and Viswanathan (1990).
} 
from other overnight information. ${ }^{11}$ In response to this potential difficulty, I could have used high-frequency intraday data for Korean and Thai stocks trading in New York as American Depository Receipts (ADRs) (see Karolyi and Stulz (1996) for the case of Japan) or country funds (see Cohen and Remolona (2000) for the case of Southeast Asia). However, there are only a few ADRs and country funds listed on the New York exchange. ${ }^{12}$ In addition, these stocks are not actively traded and do not track the underlying assets well. ${ }^{13}$ Given these drawbacks, I think the benefit of using intraday domestic total market data outweights the cost.

In addition to high-frequency data, I use the longer sample period of daily data. The sample for Korea is from January 3, 1990, through December 26, 2000, for a total of 3,081 observations. The Thailand sample period is from July 2, 1987, through December 29, 2000, for a total of 3,284 observations.

\subsection{Macroeconomic Announcement Data}

The completed data set consists of date, time, median of analysts' expectations about each macroeconomic announcement, and standard deviation of all analysts' expectations. The sample covers the period from January 1995 through December 2000. Table 3 shows details on all announcements and their mnemonic abbreviations.

The U.S. macroeconomic announcements include the Employment Report (EMP), the Producer Price Index (PPI), the Consumer Price Index (CPI), and the FOMC decisions. I separate the component of Employment Report into two parts that include Unemployment Rate (EMPU) and Nonfarm Payrolls (EMPNF). This separation is possible when I measure the announcements with the size of surprises (the sample correlation of the size of surprises is 0.07). These announcements have been shown in the literature to have a large and significant impact on U.S. financial markets (e.g., Ederington and Lee (1993), Andersen and Bollerslev

\footnotetext{
${ }^{11}$ Later in the estimation, I try to minimize this problem by using dummy variables to control for the first trading period, Monday morning, and mornings after holidays.

${ }^{12}$ There are five Korean stocks and no Thai stocks listed as ADRs. As for country funds, there are three Korean funds and two Thai funds traded on the New York Stock Exchange.

${ }^{13}$ Korean ADRs sometimes trade at premium because of ownership limits.
} 
(1998), and Jones, Lamont, and Lumsdaine (1998)). Data for the actual announcements are taken from the government agency that published them. Market expectations data are from Money Market Services (MMS). ${ }^{14}$

Japanese macroeconomic announcements include Gross Domestic Product (GDP), the Industrial Production Index (IPI), the Wholesales Price Index (WPI), the Tankan Business Survey (TK), and the Monetary Policy Meeting (MPM) decisions. These announcements are chosen based on coverage in the major Japanese financial newspaper (Nikkei Kin-yu Shimbun) and on conversations with a Bank of Japan officer. It should be noted that the Japanese Monetary Policy Committee was set up in 1998, with the U.S. FOMC as its model. The Japanese committee meets twice a month.

Korean announcements include GDP, IPI, CPI, and Trade Balance. Thai macroeconomic announcements consist of GDP, CPI, and Trade Balance. The official statistic of trade balance is reported by the Bank of Thailand in the end-of-month Press Release on Economic and Monetary Conditions. This release includes manufacturing production, private consumption, government cash balance, CPI and PPI (which are first reported by the Ministry of Commerce at the beginning of month), trade balance, liquidity conditions in financial markets, and exchange rate. I choose to focus on trade balance because it represents the most important macroeconomic factor. ${ }^{15}$

For all Asian macroeconomic announcements, the actual announcements are from the government agency that published them. For some announcements which the agency do not provide date or time, I identified it as the date and time that it first appeared on either Bloomberg News or the Dow Jones Interactive Database. Market expectations are from Consensus Economics: Asia Pacific Consensus Forecasts and Bloomberg News. Information

\footnotetext{
${ }^{14}$ Kuttner (2001) and Faust, Swanson, and Wright (2002) have shown that expectations of the FOMC decisions are better captured with the Federal Fund Futures. I choose to use MMS data because it provides a measure of market dispersion of expectations (proxy with standard deviation of all analysts' expectations). The sample correlation of the median of expectations and expectation extracted from the Federal Fund Futures is 0.99 .

${ }^{15}$ Different versions of the Thai trade balance are published independently by the Ministry of Finance (Customs Department), Ministry of Commerce (Department of Foreign Trade), and Bank of Thailand. However, the statistic from the Bank of Thailand is considered the official one.
} 
on median and standard deviation of analysts' expectations are available from 1997.

Due to the time differences among countries, trading hours, and holidays, some announcements cannot impact the market until the next trading session. The day distribution, and the earliest time that each announcement can impact Korean and Thai equity markets are shown in Appendix A1 and A2.

\section{Preliminary Analysis}

As has been shown in the literature, studies using low-frequency data (weekly and monthly) and using developed-economy financial market innovations as measure of information, find little evidence of information transmission from developed markets to emerging markets (Bekaert and Harvey (1997) and Ng (2000)). Furthermore, recent studies find that equity price dynamic can be well captured by a two-factor stochastic volatility model. Moreover, it has been shown that the impact of information (macroeconomic announcements) on volatility is short-lived. In other words, the implication is that information only impacts the short-run volatility factor. Therefore, in this section I study information transmission based on daily frequency and identify information as macroeconomic announcements. The key idea is to investigate whether daily data can provide some insights on the impact of information on the short-run volatility factor. In addition to the impact on volatility, this section also studies the impact of information on daily volume.

To test for the impact of information transmission on volatility, I estimate an $\mathrm{AR}(1)$ GARCH $(1,1)$ model in which volatility is allowed to vary with information. I measure macroeconomic announcements with dummy variables. It should be noted that although the GARCH(1,1) model is not the best fitted model, it provides a good approximation of volatility dynamic. Daily asset return is modelled as

$$
\begin{gathered}
R_{t}=\phi_{0}+\phi_{1} R_{t-1}+\epsilon_{t} \\
h_{t}=\omega+\alpha \epsilon_{t-1}^{2}+\beta h_{t-1}+\sum_{k=1}^{N_{A}} \psi_{k} I_{t}^{k}+\sum_{i=1}^{N_{D}} \varphi_{i} D_{t}^{i}
\end{gathered}
$$

where $\epsilon_{t}$ is an error term with mean zero and conditional variance $h_{t}, I^{k}$ is a dummy variable for macroeconomic announcement, $D^{i}$ is a dummy variable for day-of-the-week and days after 
holidays. The estimation results, based on daily data from 1995 through 2000, for Korea and Thailand are shown in Table 4 (Additive Volatility). From these results, it is evident that, based on daily data, we cannot capture information transmission.

The failure to capture information transmission may be explained by two issues as follows. The first issue relates to a geometric decay in volatility autocorrelation implied from the standard GARCH model. Under this autocorrelation structure, Andersen and Bollerslev (1997) pointed out that the standard GARCH model cannot capture strong regular seasonal patterns (e.g., macroeconomic announcement and day-of-the-week). To incorporate the seasonal patterns, I modify the standard GARCH model to the following form

$$
\begin{gathered}
R_{t}=\phi_{0}+\phi_{1} R_{t-1}+\sqrt{S_{t}} \epsilon_{t} \\
S_{t}=1+\sum_{k=1}^{N_{A}} \psi_{k} I_{t}^{k}+\sum_{i=1}^{N_{D}} \varphi_{i} D_{t}^{i} \\
h_{t}=\omega+\alpha \epsilon_{t-1}^{2}+\beta h_{t-1}
\end{gathered}
$$

where $S_{t}$ denotes the regular seasonal patterns. ${ }^{16}$ We can interpret this model as dummy variables enter multiplicatively into the volatility equation as opposed to additively in the first model (equation (2)). Moreover, when there are no seasonal patterns, the modified GARCH model reduces to the standard GARCH model. The estimation results are shown in Table 4 (Multiplicative Volatility ). Again, there is no evidence of information transmission.

The second issue relates to the consistency of the GARCH model. It is well known that the consistency of the GARCH model requires a long sample period. To overcome this problem, I proceed with a two-step estimation. First, daily volatility is estimated from an AR(1)-GARCH(1,1) model using the full sample of daily data (1990 through 2000 for Korea and 1987 through 2000 for Thailand). In the second step, I run a simple ordinary least squares (OLS) of volatility estimate from the GARCH model on dummies for macroeconomic announcements for a sample from 1995 through 2000. I also control for day-of-the-week and days after holidays with dummy variables. Although the two-step estimation is consistent,

\footnotetext{
${ }^{16}$ Andersen and Bollerslev (1997) introduced this modelling concept for the case of high-frequency intraday seasonal patterns (See Section 4.1). Applications on daily data were implemented in Jones, Lamont, and Lumsdaine (1998), Li and Engle (1998), and Bomfim (2000).
} 
it is not efficient. The results also show no evidence of information transmission. As a robust check of the result, I run a regression of absolute return on dummy variables for macroeconomic announcements, day-of-the-week, and days after holidays. The results show no evidence of information transmission. The results of the two-step GARCH model and absolute return are not shown. Results are available on request.

To investigate the impact of information on daily volume, I run an OLS regression of volume on dummy variables for macroeconomic announcements, day-of-the-week, and days after holidays. Table 4 (Volume) shows OLS regression results. It is evident that we can not capture information transmission. To sum up, based on daily data and measure of information as macro announcements, there is no evidence of information transmission. Given the results, there are two possible scenarios. First, there is no information transmission from the U.S. and Japan to Korea and Thailand. Second, the impact of information transmission is short-lived and cannot be captured with daily frequency. In the next section I investigate whether the second scenario is true by using high-frequency intraday data.

\section{Methodology}

\subsection{Impact of Information on Intraday Volatility}

From a recent development in price dynamic literature, volatility can be modelled as two factors: long-run (persistence) and short-run (mean-reverting) factors. An efficient way to test for the impact of macroeconomic announcements on the short-run volatility factor is to estimate jointly a two-factor stochastic volatility model. However, it is impossible to estimate a stochastic volatility model in high-frequency data because of computation cost and noise of data series. Andersen and Bollerslev $(1997,1998)$ propose a simple way to model both volatility factors in a high-frequency setting. ${ }^{17}$ Asset return is decomposed into three parts as follows:

$$
R_{t, n}-\bar{R}_{t, n}=\sigma_{t, n} S_{t, n} Z_{t, n}
$$

\footnotetext{
${ }^{17}$ The methodology in this section is based primarily on Andersen and Bollerslev (1997, 1998).
} 
where $\bar{R}_{t, n}$ is the expected fifteen-minute return for interval $n$ in day $t, n$ denotes the fifteenminute interval within a day $(n=1,2, \ldots, 16$ for Korea Subsample I and $n=1,2, \ldots, 18$ for Thailand), $Z_{t, n}$ is an error term with mean zero and unit variance, $S_{t, n}$ represents the pattern effect (calendar, scheduled announcement, and potentially short-run or mean-reverting volatility factor), and $\sigma_{t, n}$ is the remaining part (potentially long-run or persistence volatility factor). By squaring and taking log of equation (6), we get:

$$
2 \log \left[\left|R_{t, n}-\bar{R}_{t, n}\right|\right]-\log \sigma_{t, n}^{2}=c+2 \log S_{t, n}+u_{t, n}
$$

where $c=E\left[\log Z_{t, n}^{2}\right]$ and $u_{t, n}=\log Z_{t, n}^{2}-E\left[\log Z_{t, n}^{2}\right]$.

To make the estimation tractable, three assumptions are imposed as follows. First, $\bar{R}_{t, n}$ is constant. This implies that the expected return of each interval is constant across all days. This does not imply, however, that expected return is constant within a day. Second, the persistence factor, $\sigma_{t, n}^{2}$, is computed from integrated volatility (Andersen, Bollerslev, Diebold, and Labys (1999)), GARCH model, and unconditional variance. Lastly, the parametric function for $E\left[\log S_{t, n}\right]$ is imposed to be of the form $f(\theta ; t, n)$

$$
f(\theta ; t, n)=\sum_{j=0}^{J} \sigma_{t}^{j}\left[\mu_{0 j}+\mu_{1 j} n+\mu_{2 j} n^{2}+\sum_{k=1}^{D} \lambda_{k j} I_{k}(t, n)+\sum_{p=1}^{P}\left(\gamma_{p j} \cos \frac{p 2 \pi}{N} n+\delta_{p j} \sin \frac{p 2 \pi}{N} n\right)\right]
$$

where $I_{k}(t, n)$ represents an indicator for the event $\mathrm{k}$ during interval $n$ on day $t$. It should be noted that we can model the impact of event $k$ to persist for more than one period by using $I_{k}(t, n+i)$, where $i=0, \ldots, N_{k}$ and $N_{k}$ is the number of intervals during which event $k$ persists. The indicator can account for time-of-the-day effect, day-of-the-week effect, macroeconomic announcements, and important economic events. ${ }^{18}$ Later, in the empirical section, I use a different measure of macroeconomic announcements, namely, dummy variables, size of announcement surprises (measured as the absolute value of the difference between the actual announcement and the median of analysts' expectations), and the dis-

\footnotetext{
${ }^{18}$ I model five major important economic events: Thai currency crisis (July 2, 1997), Korean currency crisis (November 17, 1997), Russian crisis (August 17, 1998), Long-Term Capital Management (LTCM) crisis (September 24, 1998), and Brazilian crisis (January 13, 1999). All date and time for each event are identified as the first news that appeared on the Bloomberg News monitor. See details in Appendix B. The modelling of these events can be viewed as controlling for outlying observations.
} 
persion of announcement expectations (measured as the cross-sectional standard deviation of all analysts' forecasts for each announcement). When $J=0$ and $D=0, f(\theta ; t, n)$ reduces to a standard Flexible Fourier Functional form (Gallant (1981, 1982)). The motivation for using this functional form is its simplicity to capture the intraday pattern.

Given the assumptions, we can rewrite equation (7) as

$$
\hat{x}_{t, n} \equiv 2 \log \left[\left|R_{t, n}-\bar{R}_{t, n}\right|\right]-\log \hat{\sigma}_{t, n}^{2}=\hat{c}+f(\theta ; t, n)+\hat{u}_{t, n}
$$

where $\hat{c}=E\left[\log Z_{t, n}^{2}\right]+E\left[\log \sigma_{t, n}^{2}-\log \hat{\sigma}_{t, n}^{2}\right]$ and

$$
\begin{gathered}
\hat{u}_{t, n}=\left(\log S_{t, n}^{2}-E\left[\log S_{t, n}^{2}\right]\right)+\left(\log \sigma_{t, n}^{2}-\log \hat{\sigma}_{t, n}^{2}-E\left[\log \sigma_{t, n}^{2}-\log \hat{\sigma}_{t, n}^{2}\right]\right) \\
+\left(\log Z_{t, n}^{2}-E\left[\log Z_{t, n}^{2}\right]\right) .
\end{gathered}
$$

To estimate the model, Andersen and Bollerslev (1998) suggest a two-step estimation procedure. The first step is to calculate $\bar{R}, \hat{\sigma}_{t, n}^{2}$, and specify the lag length in the intraday pattern (equation (8)). The second step is to estimate regression of $\hat{x}_{t, n}$ on an intraday pattern function (equation (9)) by OLS. Although the two-step estimation is not efficient, it is consistent.

The last issue is to get an estimate for $\hat{\sigma}_{t, n}^{2}$ to use in the first estimation stage. The goal of this component is to capture persistence volatility factor. With several choices for estimating $\hat{\sigma}_{t, n}^{2}, \mathrm{I}$ use three different measures as follows. First, as in Andersen, Bollerslev, Diebold, and Labys (1999) show when using high-frequency data, we can measure daily volatility and treat it as observable. They termed it integrated volatility. However, integrated volatility consists of both long and short-run factors. In order to extract a long-run component, I compute a one-day ahead forecast from a time series model fitted on daily integrated volatility. The intraday estimate is

$$
\hat{\sigma}_{t, n}=\frac{\hat{\sigma}_{t}^{I n t}}{\sqrt{N}}
$$

where $\hat{\sigma}_{t}^{I n t}$ is a one-day ahead forecast of integrated volatility, $\hat{\sigma}_{t}^{I n t}$ is computed from an $\operatorname{ARMA}(1,1)$ model of integrated volatility $\left(\sigma_{t}^{\text {Int }}\right)$, and integrated volatility is computed from

$$
\sigma_{t}^{\text {Int }}=\sum_{n=1}^{N} R_{t, n}^{2}
$$


The second method is perhaps the most widely used estimation method to model volatility, I estimate $\operatorname{GARCH}(1,1)$ based on a full sample of daily data, $\hat{\sigma}_{t}^{G A R C H}$. The intraday estimate is

$$
\hat{\sigma}_{t, n}=\frac{\hat{\sigma}_{t}^{G A R C H}}{\sqrt{N}}
$$

Lastly, as a robust check of the result, I assume that $\sigma_{t, n}$ is constant by imposing it to equal the unconditional standard deviation of equity returns. The intraday estimate is

$$
\hat{\sigma}_{t, n}=\frac{\bar{\sigma}}{\sqrt{N}}
$$

where $\bar{\sigma}$ is the unconditional standard deviation.

\subsection{Impact of Information on Intraday Volume}

To study the impact of information on trading volume, I need to differentiate between the intraday pattern of volume and the impact of information on volume. From Figure 2 and 3 , intraday volumes exhibit a U-shape pattern. Following the same idea as intraday volatility, I model volume as consisting of two components: long-run and short-run components. The decomposition is analogous to equation (6), modelling intraday volume the same way as absolute return.

$$
V_{t, n}=V_{t, n}^{L R} S_{t, n} Z_{t, n}
$$

where $V_{t, n}$ is trading volume for time interval $n$ in day $t, n$ denotes the fifteen-minute interval within a day, $Z_{t, n}$ is an error term with mean zero and unit variance, $S_{t, n}$ represents the pattern effect (calendar and scheduled announcement), and $V_{t, n}^{L R}$ is the remaining part (potentially long run factor).

By taking log of equation (14), we get

$$
\log V_{t, n}-\log V_{t, n}^{L R}=c+\log S_{t, n}+u_{t, n}
$$

where $c=E\left[\log Z_{t, n}\right], u_{t, n}=\log Z_{t, n}-E\left[\log Z_{t, n}\right], V_{t, n}^{L R}$ is computed as a one-step ahead forecast from an $\operatorname{ARMA}(1,1)$ model based on daily volume. In addition, $E\left[\log S_{t, n}\right]$ is imposed to be a parametric function of the form $f(\theta ; t, n)$ similar to equation (8). Under this specification, short-run trading volume is allowed to vary with information. 


\section{$5 \quad$ Empirical Results}

I estimate the impact of information with three different empirical measures of information. Each measure, used one at a time, is allowed to vary with the short-run components of volatility and trading volume through $I_{k}(t, n)$ in equation (8). In addition, I also allow the direct impact of information to persist over different numbers of 15-minute time intervals. The three measures of information are as follows.

With the Asian macroeconomic expectation data only started in 1997 and to utilize the full sample of high-frequency data which started in 1995, I measure macro announcement occurrences with dummy variables. Each macroeconomic announcement is assigned a unique dummy variable.

The second measure is the size of announcement surprises (measured as the absolute value of the difference between the actual announcement and the median of analysts' expectations). The medians of analysts' expectations for the U.S. are obtained from the MMS. The expectations are made and reported on a monthly basis. The medians of analysts' expectations for Japan, Korea, and Thailand are made on a monthly basis but reported on a year-on-year growth rate. This leads to a problem in computing surprises for each monthly announcements. Appendix $\mathrm{C}$ explains the methodology and assumption used to convert year-on-year growth rate expectation to monthly expectation. Due to the fact that analysts' expectations for Asian announcements starts in 1997, I also estimate the model with the surprises in U.S. announcements and dummy variables for Asian announcements from 1995 through 2000 (Subsample I and II for Korea and 1995-2000 for Thailand).

Finally, I measure information with the dispersion of announcement expectations (measured as the cross-sectional standard deviation of all analysts' expectations for each announcement). This measure is intended to capture the dispersion or disagreement of agents' beliefs which can be viewed as capturing the the size of uncertainty resolved when information arrive. Disagreement of agents' belief is used widely in the microstructure theory to explain trading volume and the positive relationship between volatility and trading volume (e.g., Karpoff (1987), Kim and Verrecchia (1991), and Shalen (1993)).

With different measures of information and different operating hours for Korea, I estimate 
the impact of information with each measure separately. In addition, the estimation results for Korea are performed for each subsample separately. To conserve space, I only discuss the summary results for each country as shown in Table 8 and 9.

The estimation strategy starts from the full model then deletes and re-estimates the model until all retained information measures are significant. To illustrate of the estimation strategy, I show results on volatility for Korea Subsample I and Thailand 1995-2000 when I measure information as dummy variables (Table 5 and 6 ). The estimation starts from the column labelled Full System then proceeds to the preferred models (Model I for Korea and Model II for Thailand). To check for the robustness of the volatility results, I re-estimate the preferred model (Model I for Korea and Model II for Thailand) using GARCH and unconditional standard deviation to capture the long-run or persistence volatility factor. The results are robust to different measures of long-run volatility. This provides evidence that at a high-frequency level, the short-run component is the dominant factor similar to the results in foreign exchange market found in Andersen and Bollerslev (1998). The results for Korea Subsample I and Thailand 1995-2000 on trading volume, when information is measured as dummy variables, are shown in Table 7.

\subsection{Impact of Information on Intraday Volatility}

\subsubsection{Korea}

The top panel of Table 8 reports summary results for all Korea subsamples. The label on top of each column shows the measure of information. The empirical results on Subsample I and II should be interpreted jointly since they cover the same periods differing only on days of the week (Weekdays and Saturdays, respectively). I divided the estimation in these subsamples into two periods because the data on Asian macroeconomic expectations are only available after 1997 (Subsample I and Subsample I (From 1997) and Subsample II and Subsample II (From 1997)). The information that impact volatility are U.S. EMPNF, U.S. PPI, Japan 
IPI, Japan MPM decisions, and Korea GDP. ${ }^{19}$ The results for Subsample III and IV show that U.S. EMPNF and U.S. CPI impacts Korean equity market volatility. These impacts are significant but short-lived. On average the impact persists for about 30 minutes.

Since I estimate the impacts for different subsample, it is interesting to know how many announcements are in each subsample. Figure 4 plots the number of macro announcements that impact Korean market in each subsample. Prior to the end of 1998, most of U.S. EMPNF announcements and half of the U.S. PPI announcements impact the Korean market on Saturdays. However, I only find the impact on weekdays. The results on weekdays should be interpreted with caution.

The results on Japan MPM decisions deserve special attention. The decisions only impacted Korea's volatility during 1998. This finding might be attributed to the fact that MPM was set up in 1998 with a strong commitment from the Japanese government (they passed a new law); therefore, initially people may have paid attention to the policy. However, after a year of implementation, market participants did not observe any progress in revitalizing the Japanese economy, which may have led to a diminished impact of MPM decisions.

When I measure information from the dispersion of announcement expectations, I find a positive relationship between U.S. CPI and U.S. EMPNF and volatility (Subsample III and IV). This result is consistent with a theoretical model put forwarded by Shalen (1993). The basic idea of Shalen's model is that dispersion of agents' beliefs lead to increase in volatility and trading volume which in turn explain the positive relationship between volatility and trading volume.

\subsubsection{Thailand}

The bottom panel of Table 8 provides summary results for Thailand. It shows that U.S. EMP, U.S. FOMC, Japan IPI, and Thailand TB have a large and significant impact on market volatility. On average the impact persists for about 30 minutes. With the exception of U.S. FOMC decisions and Japan IPI, the results are robust to different measure of information.

\footnotetext{
${ }^{19}$ The detail on dynamic impact in the case of Korea Subsample I when measure information with dummy variables is in Appendix B.
} 
When I measure information as the size of surprises, I distinguish the impact from the two components in the U.S. EMP, namely, unemployment rate (EMPU) and nonfarm payrolls (EMPNF). I find that EMPNF is the important component. This announcement has also been shown in the literature as the most important announcement in the U.S. financial markets (e.g., Ederington and Lee (1993), Andersen and Bollerslev (1998), Jones, Lamont, and Lumsdaine (1998), Flannery and Protopapadakis (2002), and Andersen, Bollerslev, Diebold, and Vega (2002)). This is likely due to its timeliness and that it is perceived as a good indicator of the state of U.S. economy, and it may contain information that would help forecast the future direction of monetary policy.

The results on U.S. FOMC show the impact of monetary policy transmission. Although I do not find a significant result during the sample of 1997 to 2000, but this is not surprising. During the full sample (1995-2000), there were 49 FOMC meetings but only four decision surprises, which occurred mostly prior to 1997. This might explained why we do not find evidence in the latter sample. For results on Thailand's TB, caution in interpretation is necessary because the trade balance is reported together with other economic variables in the Bank of Thailand's monthly Press Release on Economic and Monetary Conditions (See Section 2).

\subsubsection{Economic Significance of Information}

To put the estimates in perspective, I transform the estimates into impact on market volatility by converting equations (6) through (9) to

$$
\left|R_{t, n}-\bar{R}_{t, n}\right|=\frac{\hat{\sigma}_{t}}{\sqrt{N}} \exp \left(\frac{f(\theta ; t, n)}{2}\right) \exp \left(\frac{\hat{u}_{t, n}}{2}\right)
$$

where $\hat{\sigma}_{t}$ is the daily estimate standard deviation obtained from equation (10), (12), or (13). The impact response can be computed directly from equation (16) as

$$
M(k)=\sum_{i=0}^{N_{k}}\left[\exp \left(\frac{\lambda_{k}(i)}{2}\right)-1\right]
$$

where $M(k)$ is the cumulative response from event $k$ and $\lambda_{k}(i)$ is the response of market volatility to event $k$ after $i$ interval. When $i=0, \lambda_{k}(i)$ denotes the immediate response. For example, consider the case of Korea Subsample I when information is measured as dummy 
variables (Table 5). The announcement of U.S. EMP leads Korea market volatility to increase by

$$
\begin{aligned}
& {\left[\exp \left(\frac{1.169}{2}\right)-1\right]+\left[\exp \left(\frac{1.169 \cdot(2 / 3)}{2}\right)-1\right]+\left[\exp \left(\frac{1.169 \cdot(1 / 3)}{2}\right)-1\right]} \\
& =79.41 \%+47.65 \%+21.51 \%=148.57 \%
\end{aligned}
$$

as compared to a regular period without macroeconomic announcements. In terms of volatility level, the initial impact increases by $0.635 \%$ (initial jump of $79.41 \%$ times mean of volatility over the first trading period of $0.8 \%$ ) while the second and third lags increase by $0.152 \%$ ( $47.65 \%$ times $0.32 \%$ ) and $0.058 \%$ (21.51\% times $0.27 \%$ ), respectively. It should be noted that the results indicate a very significant impact of information transmission. Figure 5 shows the impact of U.S. EMP on Korean return volatility. Figure 6 and 7 show the impact of the U.S. EMP and Thailand TB on Thai equity market volatility.

The bottom part of Tables 5 and 6 gives estimates of the impact of important economic events, namely the Thai crisis, Korean crisis, Russian crisis, LTCM crisis, and Brazilian crisis. It is evident that the impacts are very pronounced and persistent (See details in Appendix B). This is not surprising since these events were unexpected and considered ex post to have been important events in the financial markets. As I identified each event by its first appearance on the Bloomberg News monitor, it is interesting to note that the impacts of these events are transmitted to Korea and Thailand very rapidly.

To evaluate the performance of the model, I take an unconditional expectation of equation (16). Figure 8 shows the average intraday volatility for Korea and Thailand and the fitted average intraday volatility. Although it should be kept in mind that I estimate intraday pattern of log volatility, it is evident that the model can capture the average intraday volatility pattern well.

\section{$5.2 \quad$ Impact of Information on Volume}

It is by now well-established that information impacts both volatility and volume (e.g., Tauchen and Pitts (1983) and Karpoff (1987)). However, there has been little study on volume. The results on trading volume can be used as a robust check of the results from volatility. In addition, studying volume is important to understand the transmission of 
information in resolving differences of agents' beliefs which I model with the dispersion of announcement expectations.

\subsubsection{Korea}

The upper panel of Table 9 summarizes empirical results on trading volume for Korea. The label on top of each column shows the empirical measure of information. The results show that prior to the end of 1998 (Subsample I and II) U.S. FOMC decisions, Japan IPI, Japan MPM decisions, Korea GDP, Korea CPI, and Korea TB have a robust large but shortlived impact on trading volume. In addition, I find that the dispersion of announcement expectations about the U.S. FOMC decisions, Japan IP, and Korea CPI have a positive relationship with trading volume. This results are consistent with theoretical model in the microstructure literature. After the end of 1998 (Subsample III and IV), the announcement of Japan MPM decisions is the only information that impact Korean market trading volume.

Comparing the results on trading volume and volatility, prior to the end of 1998 , the information that impact both variables are Japan IPI, Japan MPM decisions, and Korea GDP. This finding can also explain the positive relationship between volatility and trading volume (Tauchen and Pitts (1983), Admati and Pfleiderer (1988), and Foster and Viswanathan (1990)). However, it is interesting to note that after the end of 1998 Japan MPM decisions only affected trading volume but not volatility. This finding is reassuring that there is information transmission from the Japan to Korea.

\subsubsection{Thailand}

The bottom of panel of Table 9 summarizes the results on impact of information on Thailand trading volume. I find that announcements about the U.S. EMPNF, U.S. FOMC decisions, Japan IPI and Thailand GDP have a large and significant on volume. I also find a positive relationship between the dispersion of expectations of announcement about U.S. EMPNF and U.S. FOMC and trading volume.

The results on the U.S. FOMC decisions are interesting. I only find the impact on volatility for the full sample (Thailand 1995-2000). However, I find a significant and robust 
positive relationships between the dispersion of expectations and trading volume. A plausible explanation can be linked to the fact that volume relates to the dispersion of agents' beliefs whereas volatility relates to an average agent expectation (e.g., Karpoff (1986), Kim and Verrecchia (1991), Shalen (1993), and Harris and Raviv (1993)). While most announcements from the FOMC decisions are expected by an average market participant (implying no measured announcement surprises), but the expectations of individual market participants may be dispersed. ${ }^{20}$

Comparing the results on volatility and trading volume, the announcements of U.S. EMPNF and Japan IPI have a significant on the Thai equity market. This finding confirms that there is information transmission from the U.S. and Japan to Thailand.

\subsubsection{Economic Significance of Information}

To evaluate the impact of each announcement, I follow the methodology used in the Subsection 5.1.3 (equation (16)). Figure 6 shows the response of Thailand trading volume to the announcement of the U.S. EMP. It is interesting to note that the impact from important economic events on volume are more persistent than the impact on volatility (See Appendix $\mathrm{B})$.

The performance of the model is evaluated by comparing the averages of the intraday volume with the averages of the fitted intraday volume. Figure 9 shows the comparison for Korea Subsample I and Thailand when I measure information with dummy variables. The plots indicate that the model can capture intraday volume well.

\section{Conclusion}

To summarize, using a measure of high-frequency intraday volatility, I find that information from the U.S. and Japan have a significantly large but short-lived impact on Korean and Thai equity markets (on average they last about 30 minutes). This in turn explains why

\footnotetext{
${ }^{20}$ From 1995 through 2000, there were forty-nine FOMC meetings. There were only four surprises. However, there were twenty-four announcements in which analysts have dispersed expectations.
} 
previous studies based on lower frequency data have generally been unable to find any effects.

Furthermore, unlike most previous studies, which only investigate information transmission through the impact on return volatility, this paper makes a first attempt to model the transmission through intraday volume. The results show strong and significant evidence of information transmission through this channel as well. In addition, these effects are also short-lived (on average they last about 45 minutes).

Although the results on volatility and trading volume are not exactly the same, prior to the end of 1998 Japan IPI, Japan MPM decisions, and Korea GDP impact both financial variables on Korean market. As for Thailand, U.S. EMPNF and Japan IPI affect both Thai equity market trading volume and volatility. I regard this finding as providing the first robust evidence of information transmission from developed economies to emerging economies' equity markets. In addition, these results are reassuring as one of the main themes of financial economics is the linkage between macroeconomic fundamentals and asset price dynamics.

It might be surprising that we do not find much evidence of the impact of domestic economy announcements on domestic financial market variables, volatility and trading volume. One plausible explanation is that on many occasions, announcements were leaked before the official time. By searching Bloomberg News and Dow Jones Database, I find several occasions when high level government cabinet members accidentally announced information before the actual official times.

Several issues merit further exploration. First, it would be interesting to investigate the impact of U.S. and Japanese macroeconomic announcements on other international equity markets. If a similar set of announcements are affecting other countries, they might constitute good candidates for identifying risk factors in the international asset pricing model. Another possibility would be to compare the importance of the transmission of public and private information. This can be achieved by using high-frequency intraday data and estimating the impact of public information (e.g., macroeconomic announcements) on the U.S. and Japan's equity market volatility. One could then try to decompose sources of volatility from the U.S. and Japan as coming from public and private information. 


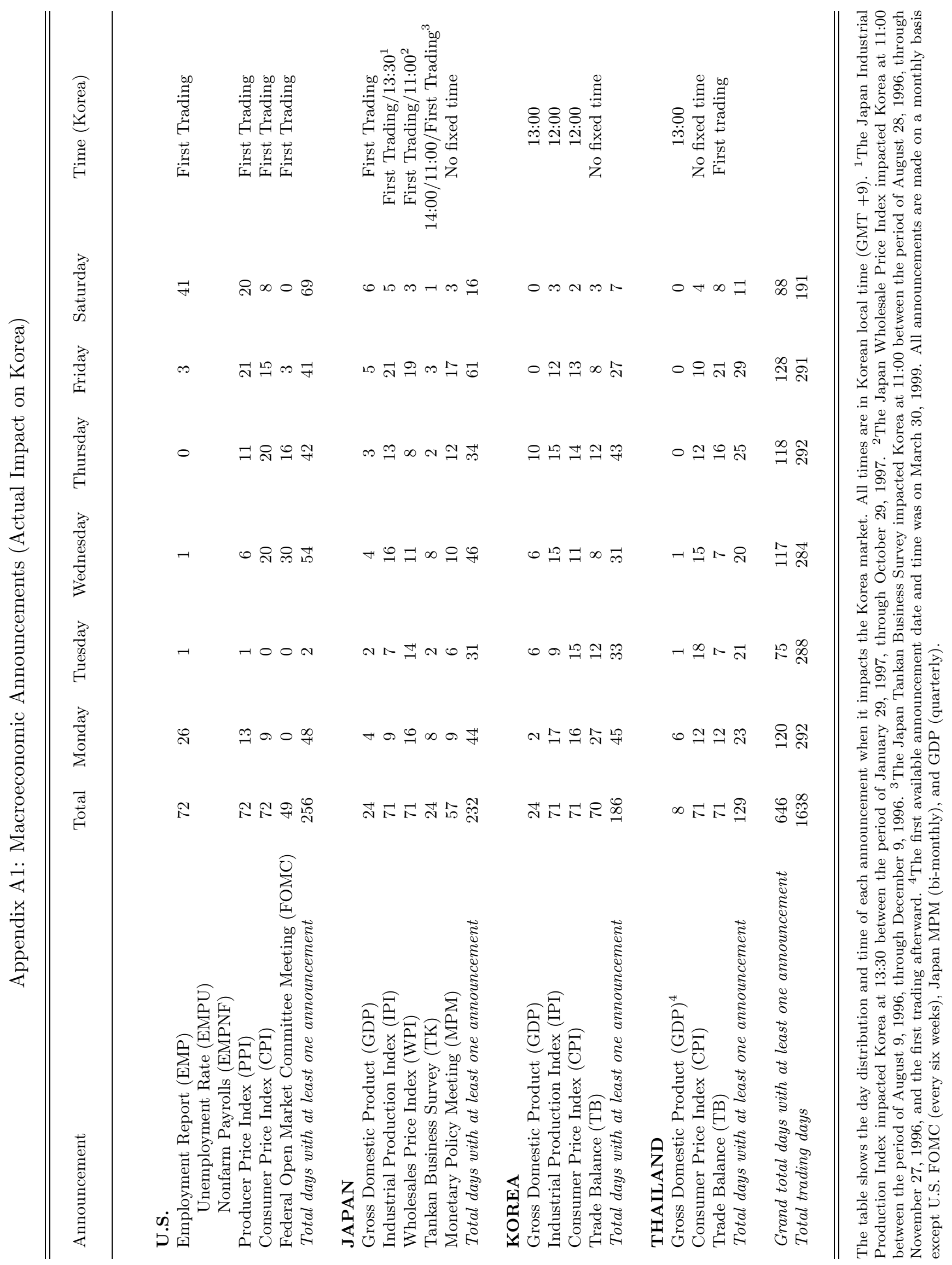




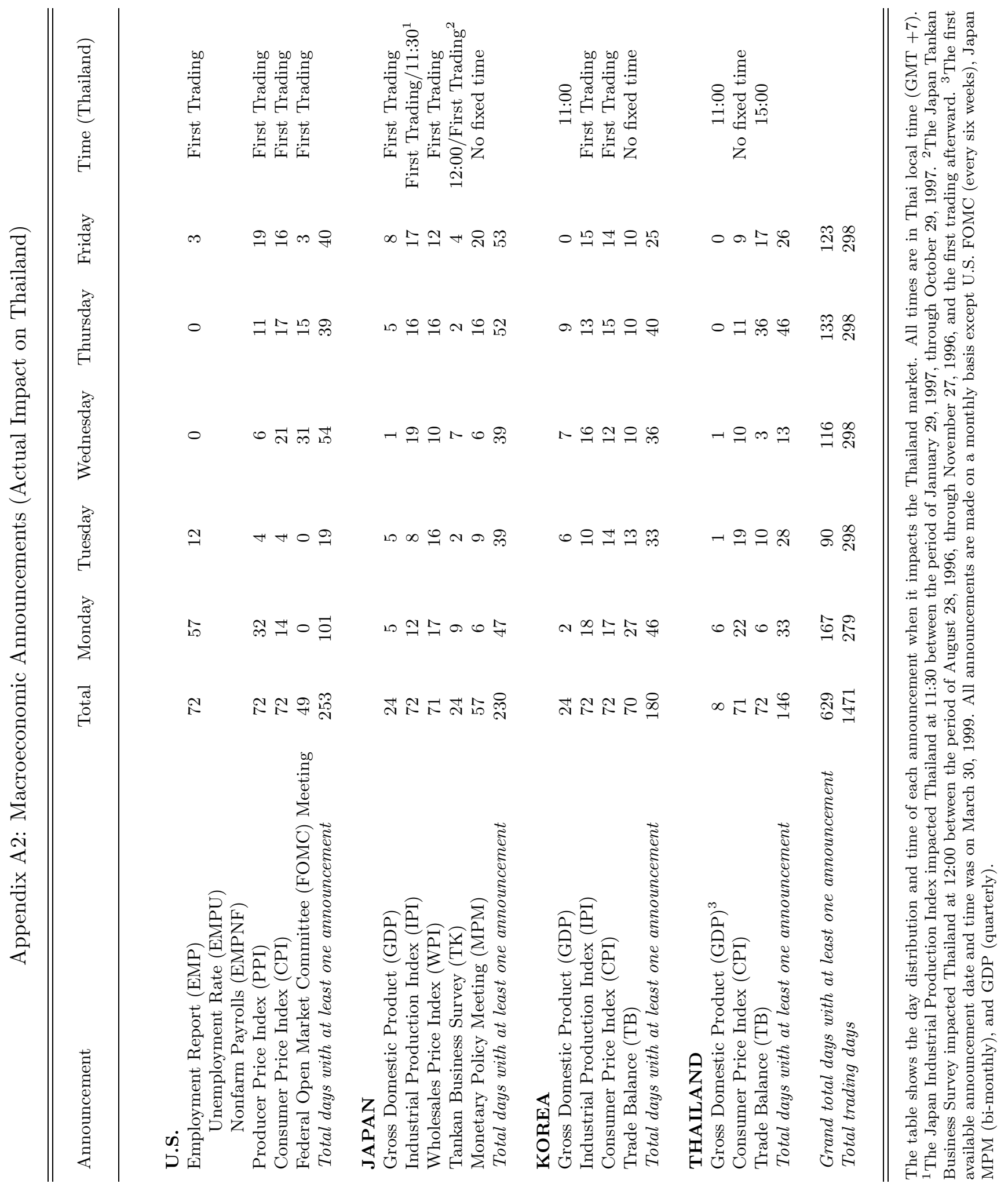




\section{Appendix B: Dynamic Response Patterns of Macroeconomic Announcements and Important Economic Events}

To allow for dynamic response of macroeconomic announcements and important economic events with parsimonious and efficient estimates, I follow the methodology used in Andersen and Bollerslev (1998). The dynamic response is captured by an order-p polynomial specification,

$$
\lambda_{k}(i)=c_{0}+c_{1} \cdot i+\ldots+c_{p} \cdot i^{p}
$$

where $\lambda_{k}(i)$ is the response of event $k$ after $i$ interval (equation (8)), $i=0, \ldots, N_{k}$, and $N_{k}$ is the number of intervals during which event $k$ persists. It should be noted that when $i=0$, it represents the initial impacts from event $k$. To gain the efficiency from the estimates, the restriction on the end point is imposed $\left(\lambda_{k}\left(N_{k}+1\right)=0\right)$. The next step is to substitute $i=N_{k}+1$ into $\lambda_{k}(i)$ and solve for $c_{p}$. Then substitute $c_{p}$ back into $\lambda_{k}(i)$. This would reduce one parameter from the p-order polynomial,

$$
\lambda_{k}(i)=c_{0} \cdot\left[1-\left(\frac{i}{N_{k}+1}\right)^{p}\right]+c_{1} \cdot\left[1-\left(\frac{i}{N_{k}+1}\right)^{p-1}\right] \cdot i+\ldots+c_{p-1} \cdot\left[1-\left(\frac{i}{N_{k}+1}\right)\right] \cdot i^{p-1}
$$

The date and time of important economic events are identified by their first appearance on the Bloomberg News monitor. The events covered are

$\begin{array}{lll}\text { Economic Events } & \text { Date } & \text { Time } \\ \text { Thai Crisis } & \text { July 2, 1997 } & \text { 1:12 GMT } \\ \text { Korea Crisis } & \text { November 17, 1997 } & 7: 45 \mathrm{GMT} \\ \text { Russian Crisis } & \text { August 17, 1998 } & 6: 19 \mathrm{GMT} \\ \text { LTCM Crisis } & \text { September 24, 1998 } & \text { 1:42 GMT } \\ \text { Brazilian Crisis } & \text { January 13, 1999 } & 8: 17 \mathrm{GMT}\end{array}$

The dynamic responses for each macroeconomic announcement and important economic event are as follows: 


\section{Korea Volatility}

U.S. Employment Report

$\begin{array}{ll}N_{k}=2 & P=1 \\ N_{k}=1 & P=1 \\ N_{k}=3 & P=2 \\ N_{k}=3 & P=2 \\ N_{k}=2 & P=1 \\ N_{k}=2 & P=1\end{array}$

Japan MPM

Thai Crisis

Korea Crisis

Russian Crisis

LTCM Crisis

\section{Thailand Volatility}

U.S. Employment Report

$N_{k}=1$

$P=1$

Thailand Trade Balance

$N_{k}=1$

$P=1$

Thai Crisis

$N_{k}=3$

$P=1$

Korea Crisis

$N_{k}=2$

$P=1$

Russian Crisis

$N_{k}=3$

$P=2$

LTCM Crisis

$N_{k}=4$

$P=2$

Brazilian Crisis

$N_{k}=4$

$P=2$

\section{Korea Volume}

Japan MPM

$\begin{array}{ll}N_{k}=1 & P=1 \\ N_{k}=2 & P=1 \\ N_{k}=3 & P=1 \\ N_{k}=6 & P=1 \\ N_{k}=6 & P=1\end{array}$

Thai Crisis

Korea Crisis

Russian Crisis

LTCM Crisis

$N_{k}=6$

$P=1$

\section{Thailand Volume}

U.S. Employment Report

$\begin{array}{ll}N_{k}=1 & P=1 \\ N_{k}=7 & P=2 \\ N_{k}=3 & P=2 \\ N_{k}=3 & P=2 \\ N_{k}=7 & P=2 \\ N_{k}=4 & P=2\end{array}$

Thai Crisis

Korea Crisis

Russian Crisis

LTCM Crisis

Brazilian Crisis 


\section{Appendix C: Converting Analysts' Expectations Frequency}

In this appendix, I convert analysts' average year-on-year growth rate expectations to monthly growth rate expectation. ${ }^{21}$ Average year-on-year growth rate is defined as growth rate of year average. Year average is computed by averaging monthly index over a year $\left(\frac{1}{12} \sum_{i=1}^{12}\right.$ monthly index $\left._{i}\right)$. To illustrate the computation method, I use the Thailand consumer price index from 1997 through 1998 as an example. Consider the Thailand monthly consumer price index in the table below:

\begin{tabular}{ccccccccccccc}
\hline \hline Year & M1 & M2 & M3 & M4 & M5 & M6 & M7 & M8 & M9 & M10 & M11 & M12 \\
\hline 1997 & 108.1 & 108.6 & 109.2 & 109.4 & 109.8 & 110.0 & 110.8 & 113.7 & 114.2 & 115.1 & 116.1 & 116.1 \\
1998 & 117.4 & 118.2 & 119.6 & 120.4 & 121.1 & 121.7 & 121.8 & 122.3 & 122.1 & 121.9 & 121.6 & 121.1 \\
\hline \hline
\end{tabular}

The year averages for 1997 and 1998 are 111.8 and 120.8, respectively. The average yearon-year growth rate from 1997 to 1998 is $\left(\frac{120.8-111.8}{111.8}\right) \times 100=8.1 \%$. In order to convert analysts' expectations frequency, I assume that analysts' expectations are distributed equally across all months.

There are four steps to compute monthly growth rate expectation from the average yearon-year growth rate expectation. First, I compute monthly averages across all years from historical data, data prior to the sample in which I want to compute the monthly expectation. For example, suppose we are in November 1998; I compute monthly averages for November by averaging November indices from samples prior to 1998.

Second, from analysts' average year-on-year growth rate expectation and the actual indices in the previous year, I compute year average for that year. For example, suppose in November 1998 analysts' expectations for average year-on-year from 1998 to 1997 is 9\%; I compute the implied year average for 1998 which equals $121.9\left(111.8\left(1+\frac{9}{100}\right)=121.9\right)$.

Third, using the information on implied year average and assuming that analysts' expec-

\footnotetext{
${ }^{21}$ This reporting convention is in Consensus Economics: Asia Pacific Consensus Forecasts.
} 
tations are distributed equally across all months, I compute monthly expectation. Following the previous example, we have (1) the implied 1998 year average (121.9), computed in step two; (2) monthly indices in 1998 from January through October, observed in November 1998; and (3) monthly averages for all months, computed in step one. I compute the implied sum of indices for November and December 1998, which is:

$$
12 \cdot 121.9-\sum_{i=1}^{10} \text { monthly index }{ }_{i}=256.4
$$

I then compare the implied sum to the sum of November and December averages (step one) and compute and distribute the differences equally across the two months (based on the assumption made before). Suppose that November and December averages from 1990 through 1997 are 119 and 119.5, respectively; the difference in the sum is $256.4-(119+$ $119.5)=17.9$. This implies that the analysts' expectations for November 1998 is $119+$ $\left(\frac{17.9}{2}\right)=125$. The implied analysts' monthly expectations can be computed directly using the actual index level in October 1998. Following this same methodology, we can convert analysts' average year-on-year growth rate expectations to monthly growth rate expectations.

Appendix C1 shows summary statistics for monthly growth rate converted from yearon-year growth rate. To evaluate the conversion methodology, I test for unbiasedness of analysts' expectations. It should be noted that even though I use median of analysts' expectations which does not necessary imply that it should be unbiased, the test for unbiasedness constitutes a good approximation to test for the validity of the conversion methodology. The test for the predictability of analysts' expectations is performed by running a first-order autoregressive regression. R-square from the regression is shown in the last column and is evidence that there is no predictability of analysts' expectations except for Thailand GDP and CPI. 
Appendix C1: Summary Statistics of Monthly Macroeconomic Surprises

\begin{tabular}{|c|c|c|c|c|c|}
\hline Macro Variable & Mean & Std. Dev. & Min. & Max. & R-Square \\
\hline \multicolumn{6}{|l|}{ JAPAN } \\
\hline GDP & 0.020 & 0.025 & -0.005 & 0.079 & 0.001 \\
\hline Industrial Production Index & -0.002 & 0.130 & -0.552 & 0.605 & 0.000 \\
\hline Wholesale Price Index & -0.014 & 0.052 & -0.310 & 0.016 & 0.001 \\
\hline \multicolumn{6}{|l|}{ KOREA } \\
\hline GDP & -0.007 & 0.130 & -0.399 & 0.266 & 0.004 \\
\hline Industrial Production Index & 0.034 & 0.245 & -1.137 & 0.984 & 0.001 \\
\hline Consumer Price Index & -0.011 & 0.010 & -0.037 & 0.015 & 0.051 \\
\hline Trade Balance & 0.041 & 2.006 & -6.040 & 9.992 & 0.001 \\
\hline \multicolumn{6}{|l|}{ THAILAND } \\
\hline GDP & -0.007 & 0.021 & -0.036 & 0.032 & 0.269 \\
\hline Consumer Price Index & -0.020 & 0.016 & -0.055 & 0.003 & 0.655 \\
\hline Trade Balance & 0.117 & 2.396 & -9.526 & 9.903 & 0.042 \\
\hline
\end{tabular}

The table shows summary statistics of monthly macroeconomic surprises. The sample period is from January 1997 through December 2000. Mean denotes sample averages; Std. Dev. denotes standard deviation; Min. denotes minimum value; Max. denotes maximum value, and $R$-Square denotes $\mathrm{R}$-square from regression of the first-order autoregressive. 


\section{References}

Admati, Anat, and Paul C. Pfleiderer, 1988, A theory of intraday patterns: Volume and price variability, Review of Financial Studies 1, 3-40.

Alizadeh, Sussan, Michael W. Brant, and Francis X. Diebold, 2002, Range-based estimation of stochastic volatility models, Journal of Finance 57, 1047-1092.

Andersen, Torben G., Luca Benzoni, and Jesper Lund, 2001, Towards an empirical foundation for continuous-time equity return models, Working Paper Kellog Graduate School of Management, Northwestern University.

Andersen, Torben G., and Tim Bollerslev, 1997, Intraday periodicity and volatility persistence in financial markets, Journal of Empirical Finance 4, 115-158.

- 1998, Deutsche markdollar volatility: Intraday activity patterns, macroeconomic announcements, and longer run dependencies, Journal of Finance 53, $219-265$.

, Francis X. Diebold, and Paul Labys, 1999, The distribution of exchange rate volatility, NBER Working Paper No.6961.

Andersen, Torben G., Tim Bollerslev, Francis X. Diebold, and Clara Vega, 2002, Micro effect of macro announcements: Real-time price discovery in foreign exchange, American Economic Review forthcoming.

Balduzzi, Pierluigi, Edwin J. Elton, and T. Clifton Green, 1999, Economic news and the yield curve: Evidence from the u.s. treasury market, Working Paper Department of Finance, Stern School of Business, New York University.

Bekaert, Geert, and Campbell R. Harvey, 1997, Emerging equity market volatility, Journal of Financial Economics 43, 29-77.

Bomfim, Antulio N., 2000, Pre-annoucement effects, news, and volatility: Monetary policy and the stock market, Working Paper Federal Reserve Board.

Chernov, Mikhail, A. Ronald Gallant, Eric Ghysels, and George Tauchen, 2001, Alternative models for stock price dynamics, Working Paper Graduate School of Business, Columbia University.

Cheung, Yin-Wong, Jia He, and Lilian Ng, 1994, Pacific-basin stock markets and real activity, Pacific-Basin Finance Journal 2, 349-373.

Cohen, Benjamin H., and Eli M. Remolona, 2000, Information flows during the asian crisis: Evidence from closed-end funds, Working Paper Bank for International Settlements.

Connolly, Robert, and F. Albert Wang, 2002, International equity market comovements: Economic fundamentals or contagion?, Pacific-Basin Finance Journal fortcoming.

Ederington, Louis H., and Jae Ha Lee, 1993, How markets process information: News release and volatility, Journal of Finance 48, 1161-1191. 
Engle, Robert F., Takatoshi Ito, and Wen-Ling Lin, 1990, Meteor showers or heat waves? heteroskedastic intra-daily volatility in the foreign exchange market, Econometrica 58, $525-542$.

Engle, Robert F., and Gary Lee, 1999, A long-run and short-run component model of stock return volatility, in Robert F. Engle, and Halbert White, ed.: Cointegration, Causality and Forecasting - A Festschrift in Honour of Clive W. J. Granger (Oxford University Press).

Eraker, Bjørn, Michael Johannes, and Nicholas Polson, 2000, The impact of jumps in volatility and returns, Working Paper Graduate School of Business, University of Chicago.

Eun, Cheol S., and Sangdal Shim, 1989, International transmission of stock market movements, Journal of Financial and Quantitative Analysis 24, 241-256.

Faust, Jon, Eric Swanson, and Jonathan H. Wright, 2002, Identifying vars based on high frequency futures data, Working Paper Federal Reserve Board.

Flannery, Mark J., and Aris A. Protopapadakis, 2002, Macroeconomics factors do influence aggregate stock returns, Review of Financial Studies 15, 751-782.

Fleming, Michael J., and Eli M. Remolona, 1999, Price formation and liquidity in the u.s. treasury market: The response to public information, Journal of Finance 52, 1111-1130.

Foster, F. Douglas, and S. Viswanathan, 1990, A theory of the intraday variations in volume, variance, and trading costs in securities markets, Review of Financial Studies 3, 593-624.

_ 1993 , Variations in trading volume, return volatility, and trading costs: Evidence on recent price formation models, Journal of Finance 48, 187-211.

Gallant, A. Ronald, 1981, On the bias in flexible functional forms and an essentially unbiased form: The fourier flexible form, Journal of Econometrics 15, 211-245.

, 1982, Unbiased determination of production technologies, Journal of Econometrics $20,285-323$.

— Chien-Te Hsu, and George Tauchen, 1999, Using daily range data to calibrate volatility diffusions and extract the forward integrated variance, Review of Economics and Statistics 81, 617-631.

Hamao, Yasushi, Ronald W. Masulis, and Victor K. Ng, 1990, Correlation in price changes and volatility across international stock markets, Review of Financial Studies 3, 281-307.

Harris, Milton, and Artur Raviv, 1993, Differences of opinion make a horse race, Review of Financial Studies 6, 473-506.

I.M.F, 1979, Direction of Trade Statistics Yearbook (International Monetary Fund).

— , 1985, Direction of Trade Statistics Yearbook (International Monetary Fund).

— , 1991, Direction of Trade Statistics Yearbook (International Monetary Fund).

— , 1997, Direction of Trade Statistics Yearbook (International Monetary Fund).

— , 2000, Direction of Trade Statistics Yearbook (International Monetary Fund). 
Ito, Takatoshi, Richard K. Lyons, and Michael T. Melvin, 1998, Is there private information in the fx market? the tokyo experiment, Journal of Finance 53, 1111-1130.

Jones, Christ, 1999, The dynamics of stochastic volatility, Working Paper University of Rochester.

Jones, Charles M., Owen Lamont, and Robin L. Lumsdaine, 1998, Macroeconomic news and bond market volatility, Journal of Financial Economics 47, 315-337.

Karolyi, G. Andrew, 1995, A multivariate garch model of international tranmissions of stock returns and volatility: The case of the united states and canada, Journal of Business $\&$ Economic Statistics 13, 11-25.

_ and Rene M. Stulz, 1996, Why do markets move together? an investigation of u.s.-japan stock return comovements, Journal of Finance 51, 951-986.

Karpoff, Jonathan M., 1986, A theory of trading volume, Journal of Finance 41, 1069-1087.

— , 1987, The relation between price changes and trading volume: A survey, Journal of Financial and Quantitative Analysis 22, 109-126.

Kim, Oliver, and Robert E. Verrecchia, 1991, Trading volume and price reactions to public announcements, Journal of Accounting Research 29, 302-321.

Kim, Sang W., and John H. Rogers, 1995, International stock price spillovers and market liberlization: Evidence from korea, japan, and the united states, Journal of Empirical Finance 2, 117-133.

Kuttner, Kenneth N., 2001, Monetary policy surprises and interest rates: Evidence from the fed funds futures market, Journal of Monetary Economics 47, 523-544.

Li, Li, and Robert F. Engle, 1998, Macroeconomic announcements and volatility of treasury futures, Working Paper Department of Economics, University of California, San Diego.

Lin, Wen-Ling, and Takatoshi Ito, 1994, Price volatility and volume spillovers between the tokyo and new york stock markets, in Jeffrey A. Frankel, ed.: The Internationalization of Equity Markets (University of Chicago).

Lo, Andrew, and A. Craig MacKinlay, 1990, An econometric analysis of nonsynchronoustrading, Journal of Econometrics 45, 181-212.

Newey, Whitney, and Kenneth West, 1987, A simple positive semi-definite, heteroskedasticity and autocorrelation consistent covariance matrix, Econometrica 55, 703-708.

$\mathrm{Ng}$, Angela, 2000, Volatility spillover effects from japan and the us to the pacific-basin, Journal of International Money and Finance 19, 207-233.

Pan, Jun, 1999, Integrated time-series analysis of spot and option prices, Working Paper Graduate School of Business, Stanford University.

Shalen, Catherine T., 1993, Volume, volatility, and the dispersion of beliefs, Review of Financial Studies 6, 405-434.

Tauchen, George E., and Mark Pitts, 1983, The price variability-volume relationship on speculative markets, Econometrica 51, 485-505. 
Table 1: International Trade and Financial Linkages

Panel A: Bekaert and Harvey (1997)

\begin{tabular}{lcc}
\hline \hline Country & Trade/GDP & World Factor \\
\hline Korea & 0.690 & 0.018 \\
Malaysia & 1.380 & 0.236 \\
Taiwan & 0.930 & 0.060 \\
Thailand & 0.580 & 0.025 \\
\hline \hline
\end{tabular}

Panel B: Ng (2000)

\begin{tabular}{lccccc}
\hline \hline Country & Trade/GDP & U.S. Trade/Trade & Japan Trade/Trade & U.S. Factor & Japan Factor \\
\hline Korea & 0.630 & 0.261 & 0.212 & 0.014 & 0.030 \\
Malaysia & 1.350 & 0.165 & 0.212 & 0.084 & 0.040 \\
Taiwan & 0.792 & 0.281 & 0.202 & 0.011 & 0.020 \\
Thailand & 0.720 & 0.157 & 0.232 & 0.050 & 0.036 \\
\hline \hline
\end{tabular}

The table shows the size of real economic and financial linkages. Panel A is excerpted from Bekaert and Harvey (1997). It shows the size of international trade (export plus import) in relation to gross domestic product (Trade/GDP) and the fraction of emerging market volatility that can be explained by developed market volatilities (World Factor). The data sample is monthly from the 1970's through December 1992. Panel B is excerpted from Ng (2000) and various issues of the Direction of Trade Statistics Yearbook from the International Monetary Fund. It shows the size of international trade (export plus import) in relation to gross domestic product (Trade/GDP), main trading partners (U.S. Trade/Trade and Japan Trade/Trade), and the fraction of emerging market volatility that can be explained by developed market volatilities (U.S. Factor and Japan Factor). U.S. Trade/Trade shows the share of U.S. import and export on total import and export. Japan Trade/Trade shows the share of Japan import and export on total import and export. The data sample is weekly from the 1970's through the last week of December 1996. 
Table 2: Summary Statistics

\begin{tabular}{|c|c|c|c|c|c|c|}
\hline & No. Obs. & Mean & Std. Dev. & Sk. & Excess Kur. & Auto. \\
\hline \multicolumn{7}{|l|}{ Return (\%) } \\
\hline Korea (Subsample I) & 15,152 & -0.007 & $0.495^{*}$ & 0.325 & $47.754^{*}$ & -0.024 \\
\hline Korea (Subsample II) & 1,528 & 0.010 & $0.645^{*}$ & -0.738 & $36.860^{*}$ & $-0.092^{*}$ \\
\hline Korea (Subsample III) & 7,040 & 0.004 & $0.540^{*}$ & -0.666 & 22.090 & $-0.100^{*}$ \\
\hline Korea (Subsample IV) & 3,552 & 0.002 & $0.436^{*}$ & -0.021 & $3.204^{*}$ & $-0.063^{*}$ \\
\hline Thailand & 26,478 & $-0.014^{*}$ & $0.381^{*}$ & $1.351^{*}$ & $32.586^{*}$ & $0.059^{*}$ \\
\hline
\end{tabular}

\section{Volatility (\%)}

\begin{tabular}{|c|c|c|c|c|c|c|}
\hline Korea (Subsample I) & 15,152 & $0.273^{*}$ & $0.410^{*}$ & $6.720^{*}$ & $83.088^{*}$ & $0.323^{*}$ \\
\hline Korea (Subsample II) & 1,528 & $0.354^{*}$ & $0.537^{*}$ & $5.957^{*}$ & $61.354^{*}$ & $0.332^{*}$ \\
\hline Korea (Subsample III) & 7,040 & $0.388^{*}$ & $0.373^{*}$ & $4.930^{*}$ & 81.362 & $0.121^{*}$ \\
\hline Korea (Subsample IV) & 3,552 & $0.312^{*}$ & $0.302^{*}$ & $2.166^{*}$ & $6.818^{*}$ & $0.199^{*}$ \\
\hline Thailand & 26,478 & $0.239^{*}$ & $0.295^{*}$ & $5.409^{*}$ & $70.071^{*}$ & $0.254^{*}$ \\
\hline
\end{tabular}

Volume (Millions of Shares)

\begin{tabular}{|c|c|c|c|c|c|c|}
\hline Korea (Subsample I) & 15,152 & $2.706^{*}$ & $2.513^{*}$ & $3.336^{*}$ & $16.756^{*}$ & $0.809^{*}$ \\
\hline Korea (Subsample II) & 1,528 & $3.534^{*}$ & $3.451^{*}$ & $3.785^{*}$ & $23.947^{*}$ & $0.832^{*}$ \\
\hline Korea (Subsample III) & 7,040 & $12.460^{*}$ & $4.863^{*}$ & $0.892^{*}$ & $2.068^{*}$ & $0.639^{*}$ \\
\hline Korea (Subsample IV) & 3,552 & $13.266^{*}$ & $6.725^{*}$ & $2.161^{*}$ & $10.270^{*}$ & $0.722^{*}$ \\
\hline Thailand & 26,478 & $10.781^{*}$ & $13.797^{*}$ & $3.911^{*}$ & $24.866^{*}$ & $0.784^{*}$ \\
\hline
\end{tabular}

The table shows summary intraday return, volatility, and volume statistics. Return and volatility are expressed in percentages. Korea Subsample I covers the period from January 3, 1995, through December 5, 1998 (Weekdays). Korea Subsample II covers the period from January 3, 1995, through December 5, 1998 (Saturdays). Korea Subsample III covers the period from December 7, 1998, through May 19, 2000 (Weekdays). Korea Subsample IV covers the period from May 22, 2000, through December 26, 2000. Mean denotes sample averages; Std. Dev. denotes standard deviation; Sk. denotes skewness; Excess Kur. denotes excess kurtosis from Normal distribution, and Auto. denotes average intraday auto correlation. Mean, Std. Dev., Sk., and Excess Kur. are computed jointly from exactly identified GMM moment conditions with Newey and West (1987) standard errors. Auto. is computed with GMM moment conditions with Newey and West (1987) standard errors. The symbol * indicates the statistic is significant at the $95 \%$ confidence interval. 


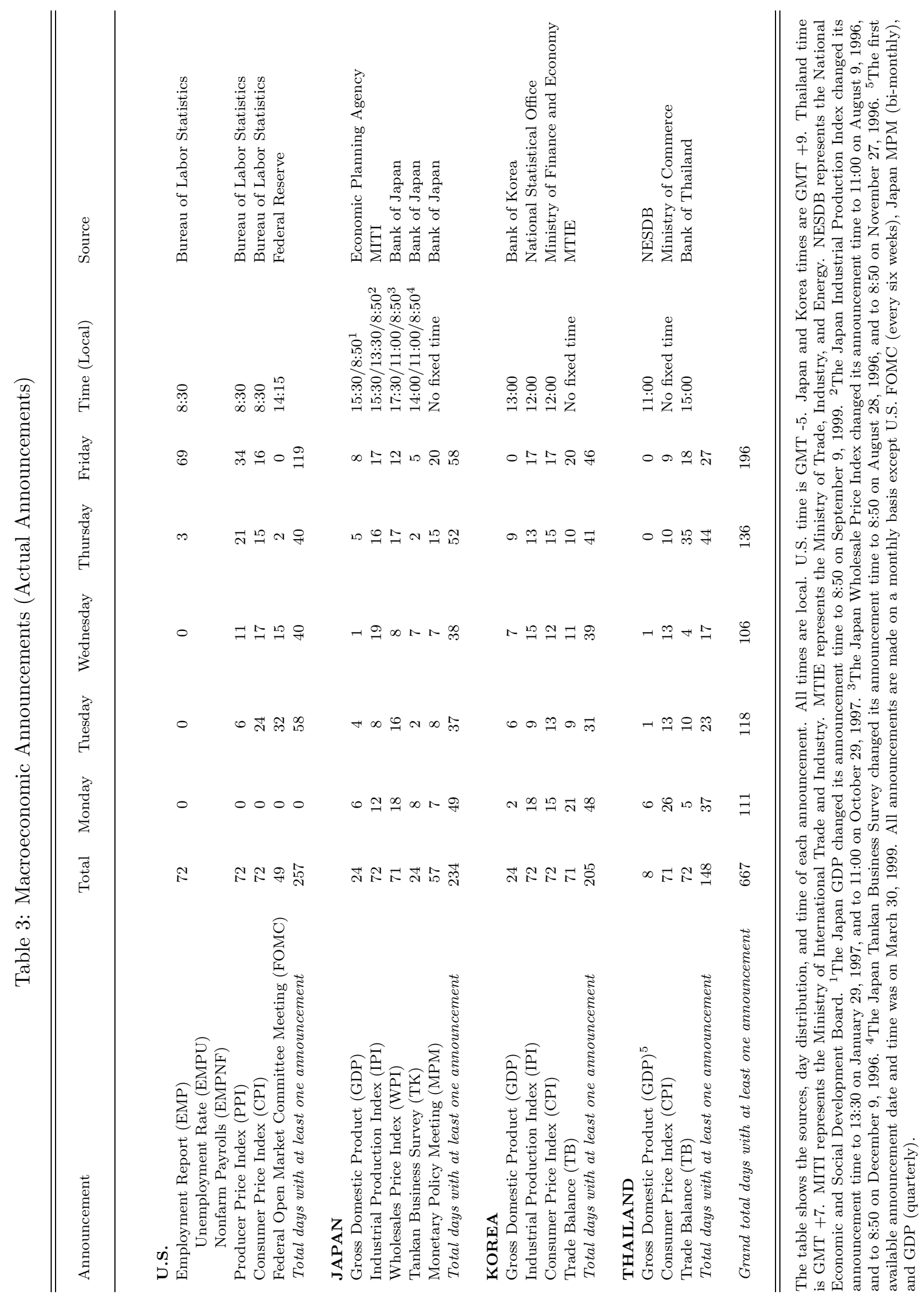


Table 4: Daily Volatility and Volume Regressions

\begin{tabular}{|c|c|c|c|c|c|c|}
\hline & \multicolumn{2}{|c|}{ Additive Volatility } & \multicolumn{2}{|c|}{ Multiplicative Volatility } & \multicolumn{2}{|c|}{ Volume } \\
\hline & Korea & Thailand & Korea & Thailand & Korea & Thailand \\
\hline Intercept & $\begin{array}{l}-0.032 \\
(0.042)\end{array}$ & $\begin{array}{c}-0.109^{*} \\
(0.029)\end{array}$ & $\begin{array}{l}-0.029 \\
(0.036)\end{array}$ & $\begin{array}{c}-0.104^{*} \\
(0.041)\end{array}$ & $\begin{array}{l}92.947^{*} \\
(6.747)\end{array}$ & $\begin{array}{l}171.445^{*} \\
(14.574)\end{array}$ \\
\hline$\phi_{1}$ & $\begin{array}{c}0.126^{*} \\
(0.027)\end{array}$ & $\begin{array}{l}0.125^{*} \\
(0.022)\end{array}$ & $\begin{array}{c}0.153^{*} \\
(0.025)\end{array}$ & $\begin{array}{l}0.121^{*} \\
(0.031)\end{array}$ & & \\
\hline$\omega$ & $\begin{array}{c}1.273^{*} \\
(0.300)\end{array}$ & $\begin{array}{l}0.913^{*} \\
(0.191)\end{array}$ & $\begin{array}{c}0.136^{*} \\
(0.034)\end{array}$ & $\begin{array}{l}0.196^{*} \\
(0.053)\end{array}$ & & \\
\hline$\alpha$ & $\begin{array}{c}0.080^{*} \\
(0.013)\end{array}$ & $\begin{array}{l}0.120^{*} \\
(0.016)\end{array}$ & $\begin{array}{c}0.185^{*} \\
(0.039)\end{array}$ & $\begin{array}{l}0.093^{*} \\
(0.039)\end{array}$ & & \\
\hline$\beta$ & $\begin{array}{c}0.818^{*} \\
(0.021)\end{array}$ & $\begin{array}{c}0.828^{*} \\
(0.018)\end{array}$ & $\begin{array}{c}0.912^{*} \\
(0.109)\end{array}$ & $\begin{array}{l}0.904^{*} \\
(0.156)\end{array}$ & & \\
\hline Tuesday & $\begin{array}{c}-1.700^{*} \\
(0.516)\end{array}$ & $\begin{array}{c}-1.867^{*} \\
(0.317)\end{array}$ & $\begin{array}{c}-0.307^{*} \\
(0.120)\end{array}$ & $\begin{array}{c}-0.590^{*} \\
(0.090)\end{array}$ & $\begin{array}{l}24.351^{*} \\
(5.442)\end{array}$ & $\begin{array}{c}8.623 \\
(10.969)\end{array}$ \\
\hline Wednesday & $\begin{array}{c}-0.807^{*} \\
(0.349)\end{array}$ & $\begin{array}{l}0.321 \\
(0.311)\end{array}$ & $\begin{array}{l}-0.181 \\
(0.014)\end{array}$ & $\begin{array}{l}0.114 \\
(0.184)\end{array}$ & $\begin{array}{l}27.870^{*} \\
(6.625)\end{array}$ & $\begin{array}{c}15.799 \\
(12.459)\end{array}$ \\
\hline Thursday & $\begin{array}{c}-1.654^{*} \\
(0.341)\end{array}$ & $\begin{array}{l}-1.678^{*} \\
(0.293)\end{array}$ & $\begin{array}{c}-0.331^{*} \\
(0.105)\end{array}$ & $\begin{array}{c}-0.452^{*} \\
(0.091)\end{array}$ & $\begin{array}{l}27.845^{*} \\
(6.117)\end{array}$ & $\begin{array}{c}28.637^{*} \\
(12.931)\end{array}$ \\
\hline Friday & $\begin{array}{c}-0.443 \\
(0.410)\end{array}$ & $\begin{array}{c}-1.023^{*} \\
(0.281)\end{array}$ & $\begin{array}{l}-0.272 \\
(0.136)\end{array}$ & $\begin{array}{c}-0.319^{*} \\
(0.139)\end{array}$ & $\begin{array}{l}22.266^{*} \\
(5.700)\end{array}$ & $\begin{array}{c}36.342^{*} \\
(13.833)\end{array}$ \\
\hline Saturday & $\begin{array}{c}-2.217^{*} \\
(0.419)\end{array}$ & & $\begin{array}{c}-0.406^{*} \\
(0.101)\end{array}$ & & $\begin{array}{r}-66.938^{*} \\
(6.158)\end{array}$ & \\
\hline After Holiday & $\begin{array}{c}0.731 \\
(0.370)\end{array}$ & $\begin{array}{c}0.379 \\
(0.220)\end{array}$ & $\begin{array}{c}0.088 \\
(0.109)\end{array}$ & $\begin{array}{c}0.187 \\
(0.096)\end{array}$ & $\begin{array}{l}-19.084 \\
(12.303)\end{array}$ & $\begin{array}{c}23.471 \\
(34.399)\end{array}$ \\
\hline \multicolumn{7}{|l|}{ U.S. } \\
\hline Employment Report & $\begin{array}{c}0.513 \\
(0.351)\end{array}$ & $\begin{array}{l}0.296 \\
(0.224)\end{array}$ & $\begin{array}{l}-0.007 \\
(0.111)\end{array}$ & $\begin{array}{l}-0.126 \\
(0.119)\end{array}$ & $\begin{array}{c}3.153 \\
(5.168)\end{array}$ & $\begin{array}{c}11.329 \\
(24.626)\end{array}$ \\
\hline Producer Price Index & $\begin{array}{l}-0.031 \\
(0.274)\end{array}$ & $\begin{array}{l}-0.116 \\
(0.259)\end{array}$ & $\begin{array}{l}-0.034 \\
(0.115)\end{array}$ & $\begin{array}{l}-0.247 \\
(0.144)\end{array}$ & $\begin{array}{c}16.315 \\
(12.202)\end{array}$ & $\begin{array}{c}-5.320 \\
(20.695)\end{array}$ \\
\hline Consumer Price Index & $\begin{array}{c}0.761 \\
(0.520)\end{array}$ & $\begin{array}{c}0.432 \\
(0.305)\end{array}$ & $\begin{array}{l}0.128 \\
(0.142)\end{array}$ & $\begin{array}{l}0.268 \\
(0.167)\end{array}$ & $\begin{array}{c}1.750 \\
(11.752)\end{array}$ & $\begin{array}{l}-10.253 \\
(18.814)\end{array}$ \\
\hline FOMC meeting & $\begin{array}{l}-0.463 \\
(0.261)\end{array}$ & $\begin{array}{l}-0.197 \\
(0.282)\end{array}$ & $\begin{array}{l}-0.129 \\
(0.138)\end{array}$ & $\begin{array}{l}0.210 \\
(0.167)\end{array}$ & $\begin{array}{c}-4.501 \\
(15.972)\end{array}$ & $\begin{array}{c}52.563 \\
(41.282)\end{array}$ \\
\hline \multicolumn{7}{|l|}{ JAPAN } \\
\hline GDP & $\begin{array}{c}0.010 \\
(0.523)\end{array}$ & $\begin{array}{l}-0.006 \\
(0.259)\end{array}$ & $\begin{array}{l}-0.108 \\
(0.156)\end{array}$ & $\begin{array}{l}-0.146 \\
(0.100)\end{array}$ & $\begin{array}{c}13.964 \\
(23.158)\end{array}$ & $\begin{array}{l}-12.408 \\
(41.016)\end{array}$ \\
\hline Industrial Production Index & $\begin{array}{l}-0.669 \\
(0.518)\end{array}$ & $\begin{array}{l}0.159 \\
(0.315)\end{array}$ & $\begin{array}{l}-0.204 \\
(0.131)\end{array}$ & $\begin{array}{l}-0.069 \\
(0.114)\end{array}$ & $\begin{array}{l}-7.183 \\
(9.493)\end{array}$ & $\begin{array}{l}-30.011 \\
(16.017)\end{array}$ \\
\hline Wholesale Price Index & $\begin{array}{c}0.122 \\
(0.384)\end{array}$ & $\begin{array}{l}-0.048 \\
(0.317)\end{array}$ & $\begin{array}{c}0.084 \\
(0.129)\end{array}$ & $\begin{array}{c}0.171 \\
(0.120)\end{array}$ & $\begin{array}{c}8.166 \\
(13.290)\end{array}$ & $\begin{array}{c}-0.904 \\
(20.182)\end{array}$ \\
\hline
\end{tabular}


Table 4: Daily Volatility and Volume Regressions (Continued)

\begin{tabular}{|c|c|c|c|c|c|c|}
\hline & \multicolumn{2}{|c|}{ Additive Volatility } & \multicolumn{2}{|c|}{ Multiplicative Volatility } & \multicolumn{2}{|c|}{ Volume } \\
\hline & Korea & Thailand & Korea & Thailand & Korea & Thailand \\
\hline Tankan Survey & $\begin{array}{l}-0.103 \\
(0.561)\end{array}$ & $\begin{array}{l}-0.073 \\
(0.202)\end{array}$ & $\begin{array}{c}-0.148 \\
(0.161)\end{array}$ & $\begin{array}{l}-0.156 \\
(0.094)\end{array}$ & $\begin{array}{c}6.858 \\
(24.962)\end{array}$ & $\begin{array}{l}-19.519 \\
(44.113)\end{array}$ \\
\hline Monetary Policy Meeting & $\begin{array}{c}1.028 \\
(0.662)\end{array}$ & $\begin{array}{c}0.145 \\
(0.386)\end{array}$ & $\begin{array}{l}0.278 \\
(0.226)\end{array}$ & $\begin{array}{c}0.433 \\
(0.288)\end{array}$ & $\begin{array}{l}-8.622 \\
(8.538)\end{array}$ & $\begin{array}{l}-20.147 \\
(11.527)\end{array}$ \\
\hline \multicolumn{7}{|l|}{ KOREA } \\
\hline GDP & $\begin{array}{c}0.034 \\
(0.536)\end{array}$ & $\begin{array}{l}-0.383 \\
(0.274)\end{array}$ & $\begin{array}{c}0.018 \\
(0.178)\end{array}$ & $\begin{array}{l}-0.094 \\
(0.093)\end{array}$ & $\begin{array}{c}-5.913 \\
(20.945)\end{array}$ & $\begin{array}{l}-13.703 \\
(35.099)\end{array}$ \\
\hline Industrial Production Index & $\begin{array}{c}0.041 \\
(0.557)\end{array}$ & $\begin{array}{c}0.215 \\
(0.277)\end{array}$ & $\begin{array}{c}0.024 \\
(0.119)\end{array}$ & $\begin{array}{c}0.329 \\
(0.189)\end{array}$ & $\begin{array}{l}-0.726 \\
(9.108)\end{array}$ & $\begin{array}{c}-2.860 \\
(18.433)\end{array}$ \\
\hline Consumer Price Index & $\begin{array}{c}0.277 \\
(0.486)\end{array}$ & $\begin{array}{c}0.137 \\
(0.261)\end{array}$ & $\begin{array}{c}0.187 \\
(0.204)\end{array}$ & $\begin{array}{l}-0.075 \\
(0.150)\end{array}$ & $\begin{array}{c}-3.512 \\
(10.591)\end{array}$ & $\begin{array}{c}-1.443 \\
(19.674)\end{array}$ \\
\hline Trade Balance & $\begin{array}{l}-0.359 \\
(0.431)\end{array}$ & $\begin{array}{c}0.828 \\
(0.654)\end{array}$ & $\begin{array}{c}0.108 \\
(0.222)\end{array}$ & $\begin{array}{l}0.234 \\
(0.288)\end{array}$ & $\begin{array}{l}11.063 \\
(8.937)\end{array}$ & $\begin{array}{c}4.479 \\
(22.636)\end{array}$ \\
\hline \multicolumn{7}{|l|}{ THAILAND } \\
\hline GDP & $\begin{array}{l}-0.081 \\
(0.147)\end{array}$ & $\begin{array}{l}-1.032 \\
(0.728)\end{array}$ & $\begin{array}{l}-0.061 \\
(0.310)\end{array}$ & $\begin{array}{l}-0.194 \\
(0.161)\end{array}$ & $\begin{array}{c}6.737 \\
(8.439)\end{array}$ & $\begin{array}{c}79.461 \\
(82.253)\end{array}$ \\
\hline Consumer Price Index & $\begin{array}{l}0.054 \\
(0.385)\end{array}$ & $\begin{array}{c}0.637 \\
(0.359)\end{array}$ & $\begin{array}{c}0.004 \\
(0.132)\end{array}$ & $\begin{array}{l}0.268 \\
(0.241)\end{array}$ & $\begin{array}{c}7.427 \\
(11.121)\end{array}$ & $\begin{array}{c}2.558 \\
(22.207)\end{array}$ \\
\hline Trade Balance & $\begin{array}{c}0.678 \\
(0.436)\end{array}$ & $\begin{array}{l}-0.259 \\
(0.359)\end{array}$ & $\begin{array}{c}0.248 \\
(0.199)\end{array}$ & $\begin{array}{l}-0.024 \\
(0.126)\end{array}$ & $\begin{array}{l}3.907 \\
(9.746)\end{array}$ & $\begin{array}{c}7.208 \\
(22.064)\end{array}$ \\
\hline
\end{tabular}

The table shows estimates of macroeconomic announcements on daily volatility and volume for Korea and Thailand. Additive Volatility shows regression results for GARCH model with additive macroeconomic announcements dummies (equation (2)). Multiplicative Volatility shows regression results for GARCH model with multiplicative macroeconomic announcements dummies (equation (4) and (5)). Volume shows regression results for trading volume on macroeconomic announcements dummies. The sample period for Korea is from January 5, 1995, through December 26, 2000. The sample period for Thailand is from January 3, 1995, through December 29, 2000. Newey and West (1987) robust standard errors are in parenthesis. The symbol * indicates the estimate is significant at the $95 \%$ confidence interval. 
Table 5: Korea Subsample I Intraday Volatility Regression

\begin{tabular}{|c|c|c|c|c|}
\hline & Full System & Model I & GARCH & Std \\
\hline Intercept & $\begin{array}{c}0.247 \\
(0.404)\end{array}$ & $\begin{array}{c}0.188 \\
(0.397)\end{array}$ & $\begin{array}{c}0.461 \\
(0.395)\end{array}$ & $\begin{array}{l}-0.022 \\
(0.407)\end{array}$ \\
\hline$\mu_{1}$ & $\begin{array}{c}-0.888^{*} \\
(0.127)\end{array}$ & $\begin{array}{c}-0.870^{*} \\
(0.125)\end{array}$ & $\begin{array}{c}-0.874^{*} \\
(0.125)\end{array}$ & $\begin{array}{c}-0.868^{*} \\
(0.126)\end{array}$ \\
\hline$\mu_{2}$ & $\begin{array}{l}0.053^{*} \\
(0.008)\end{array}$ & $\begin{array}{c}0.052^{*} \\
(0.007)\end{array}$ & $\begin{array}{l}0.052^{*} \\
(0.007)\end{array}$ & $\begin{array}{c}0.052^{*} \\
(0.007)\end{array}$ \\
\hline$\gamma_{1}$ & $\begin{array}{c}-0.818^{*} \\
(0.173)\end{array}$ & $\begin{array}{c}-0.798^{*} \\
(0.171)\end{array}$ & $\begin{array}{c}-0.802^{*} \\
(0.171)\end{array}$ & $\begin{array}{c}-0.792^{*} \\
(0.173)\end{array}$ \\
\hline$\delta_{1}$ & $\begin{array}{c}0.121 \\
(0.068)\end{array}$ & $\begin{array}{c}0.127 \\
(0.066)\end{array}$ & $\begin{array}{l}0.126 \\
(0.067)\end{array}$ & $\begin{array}{l}0.130 \\
(0.067)\end{array}$ \\
\hline Monday Morning & $\begin{array}{c}0.607^{*} \\
(0.191)\end{array}$ & $\begin{array}{c}0.588^{*} \\
(0.187)\end{array}$ & $\begin{array}{c}0.593^{*} \\
(0.185)\end{array}$ & $\begin{array}{c}0.581^{*} \\
(0.199)\end{array}$ \\
\hline First Morning Trading & $\begin{array}{l}0.762^{*} \\
(0.161)\end{array}$ & $\begin{array}{c}0.800^{*} \\
(0.145)\end{array}$ & $\begin{array}{l}0.806^{*} \\
(0.145)\end{array}$ & $\begin{array}{c}0.793^{*} \\
(0.146)\end{array}$ \\
\hline First Afternoon Trading & $\begin{array}{l}0.551^{*} \\
(0.087)\end{array}$ & $\begin{array}{c}0.557^{*} \\
(0.084)\end{array}$ & $\begin{array}{c}0.557^{*} \\
(0.084)\end{array}$ & $\begin{array}{c}0.560^{*} \\
(0.084)\end{array}$ \\
\hline Last Trading & $\begin{array}{c}-2.386^{*} \\
(0.157)\end{array}$ & $\begin{array}{c}-2.375^{*} \\
(0.156)\end{array}$ & $\begin{array}{c}-2.375^{*} \\
(0.156)\end{array}$ & $\begin{array}{c}-2.377^{*} \\
(0.157)\end{array}$ \\
\hline After Holiday & $\begin{array}{c}-0.440^{*} \\
(0.188)\end{array}$ & $\begin{array}{c}-0.429^{*} \\
(0.185)\end{array}$ & $\begin{array}{l}-0.315 \\
(0.184)\end{array}$ & $\begin{array}{c}-0.497^{*} \\
(0.166)\end{array}$ \\
\hline Tuesday & $\begin{array}{l}0.238^{*} \\
(0.080)\end{array}$ & $\begin{array}{c}0.238^{*} \\
(0.080)\end{array}$ & $\begin{array}{l}0.200^{*} \\
(0.076)\end{array}$ & $\begin{array}{l}0.208^{*} \\
(0.102)\end{array}$ \\
\hline Wednesday & $\begin{array}{l}0.230^{*} \\
(0.087)\end{array}$ & $\begin{array}{c}0.231^{*} \\
(0.086)\end{array}$ & $\begin{array}{l}0.179^{*} \\
(0.079)\end{array}$ & $\begin{array}{c}0.188 \\
(0.118)\end{array}$ \\
\hline Thursday & $\begin{array}{l}0.270^{*} \\
(0.083)\end{array}$ & $\begin{array}{c}0.268^{*} \\
(0.082)\end{array}$ & $\begin{array}{l}0.217^{*} \\
(0.078)\end{array}$ & $\begin{array}{c}0.201 \\
(0.111)\end{array}$ \\
\hline Friday & $\begin{array}{l}0.229^{*} \\
(0.091)\end{array}$ & $\begin{array}{c}0.225^{*} \\
(0.091)\end{array}$ & $\begin{array}{l}0.157 \\
(0.085)\end{array}$ & $\begin{array}{c}0.197 \\
(0.109)\end{array}$ \\
\hline \multicolumn{5}{|l|}{ U.S. } \\
\hline Employment Report & $\begin{array}{l}0.999^{*} \\
(0.440)\end{array}$ & $\begin{array}{c}1.169^{*} \\
(0.411)\end{array}$ & $\begin{array}{c}0.557 \\
(0.306)\end{array}$ & $\begin{array}{c}1.443^{*} \\
(0.528)\end{array}$ \\
\hline Producer Price Index & $\begin{array}{l}-0.176 \\
(0.555)\end{array}$ & & & \\
\hline Consumer Price Index & $\begin{array}{l}-0.023 \\
(0.344)\end{array}$ & & & \\
\hline FOMC meeting & $\begin{array}{c}0.238 \\
(0.391)\end{array}$ & & & \\
\hline \multicolumn{5}{|l|}{ JAPAN } \\
\hline GDP & $\begin{array}{l}-0.302 \\
(0.765)\end{array}$ & & & \\
\hline
\end{tabular}


Table 5: Korea Subsample I Intraday Volatility Regression (Continued)

\begin{tabular}{lcccc}
\hline \hline & Full System & Model I & GARCH & Std \\
& & & & \\
Industrial Production Index & 0.579 & & & \\
& $(0.437)$ & & & \\
Wholesale Price Index & 0.078 & & & \\
& $(0.404)$ & & & \\
Tankan Survey & -0.363 & & & \\
& $(0.831)$ & & & \\
Monetary Policy Meeting & $1.895^{*}$ & $1.882^{*}$ & $1.455^{*}$ & $2.574^{*}$ \\
& $(0.383)$ & $(0.378)$ & $(0.403)$ & $(0.408)$
\end{tabular}

\section{KOREA}

$\begin{array}{lc}\text { GDP } & 0.447 \\ & (0.520) \\ \text { Industrial Production Index } & -0.206 \\ & (0.351) \\ \text { Consumer Price Index } & 0.149 \\ & (0.323) \\ \text { Trade Balance } & 0.030 \\ & (0.253)\end{array}$

THAILAND

Consumer Price Index $\quad 0.213$

$(0.251)$

Trade Balance $\quad-0.480$

$(0.386)$

\section{ECONOMIC EVENTS}

Thai Crisis

Korean Crisis

Russian Crisis

LTCM Crisis

\begin{tabular}{|c|c|c|c|}
\hline $\begin{array}{l}2.388^{*} \\
(0.257)\end{array}$ & $\begin{array}{c}2.563^{*} \\
(0.142)\end{array}$ & $\begin{array}{c}2.704^{*} \\
(0.133)\end{array}$ & $\begin{array}{c}2.286^{*} \\
(0.163)\end{array}$ \\
\hline $\begin{array}{c}-1.037^{*} \\
(0.336)\end{array}$ & $\begin{array}{c}-1.177^{*} \\
(0.199)\end{array}$ & $\begin{array}{c}-1.100^{*} \\
(0.185)\end{array}$ & $\begin{array}{c}-1.310^{*} \\
(0.229)\end{array}$ \\
\hline $\begin{array}{c}4.692^{*} \\
(0.239)\end{array}$ & $\begin{array}{l}4.680^{*} \\
(0.238)\end{array}$ & $\begin{array}{c}3.915^{*} \\
(0.270)\end{array}$ & $\begin{array}{c}5.350^{*} \\
(0.212)\end{array}$ \\
\hline $\begin{array}{c}-4.901^{*} \\
(0.319)\end{array}$ & $\begin{array}{c}-4.886^{*} \\
(0.321)\end{array}$ & $\begin{array}{c}-5.214^{*} \\
(0.379)\end{array}$ & $\begin{array}{c}-4.569^{*} \\
(0.213)\end{array}$ \\
\hline $\begin{array}{c}3.827^{*} \\
(0.210)\end{array}$ & $\begin{array}{l}3.823^{*} \\
(0.207)\end{array}$ & $\begin{array}{c}3.623^{*} \\
(0.204)\end{array}$ & $\begin{array}{c}3.802^{*} \\
(0.216)\end{array}$ \\
\hline $\begin{array}{c}3.962^{*} \\
(0.221)\end{array}$ & $\begin{array}{c}3.955^{*} \\
(0.216)\end{array}$ & $\begin{array}{c}3.345^{*} \\
(0.213)\end{array}$ & $\begin{array}{c}3.767^{*} \\
(0.224)\end{array}$ \\
\hline
\end{tabular}

The table shows estimates of intraday volatility regression for the Korea Subsample I. Newey and West (1987) robust standard errors with 18 lags correction are in parentheses. The symbol * indicates the estimate is significant at the $95 \%$ confidence interval. Details on dynamic response are in Appendix B. 
Table 6: Thailand Intraday Volatility Regression

\begin{tabular}{|c|c|c|c|c|c|}
\hline & Full System & Model I & Model II & GARCH & Std \\
\hline Intercept & $\begin{array}{l}3.192^{*} \\
(0.582)\end{array}$ & $\begin{array}{l}3.310^{*} \\
(0.326)\end{array}$ & $\begin{array}{l}3.437^{*} \\
(0.321)\end{array}$ & $\begin{array}{c}3.061^{*} \\
(0.320)\end{array}$ & $\begin{array}{c}2.958^{*} \\
(0.324)\end{array}$ \\
\hline$\mu_{1}$ & $\begin{array}{c}-1.466^{*} \\
(0.156)\end{array}$ & $\begin{array}{c}-1.482^{*} \\
(0.095)\end{array}$ & $\begin{array}{c}-1.502^{*} \\
(0.094)\end{array}$ & $\begin{array}{c}-1.503^{*} \\
(0.094)\end{array}$ & $\begin{array}{c}-1.502^{*} \\
(0.095)\end{array}$ \\
\hline$\mu_{2}$ & $\begin{array}{l}0.073^{*} \\
(0.008)\end{array}$ & $\begin{array}{c}0.074^{*} \\
(0.005)\end{array}$ & $\begin{array}{c}0.074^{*} \\
(0.005)\end{array}$ & $\begin{array}{c}0.075^{*} \\
(0.005)\end{array}$ & $\begin{array}{c}0.075^{*} \\
(0.005)\end{array}$ \\
\hline$\gamma_{1}$ & $\begin{array}{c}-1.699^{*} \\
(0.231)\end{array}$ & $\begin{array}{c}-1.718^{*} \\
(0.160)\end{array}$ & $\begin{array}{c}-1.747^{*} \\
(0.159)\end{array}$ & $\begin{array}{c}-1.750^{*} \\
(0.159)\end{array}$ & $\begin{array}{c}-1.750^{*} \\
(0.160)\end{array}$ \\
\hline$\delta_{1}$ & $\begin{array}{c}-0.532^{*} \\
(0.097)\end{array}$ & $\begin{array}{c}-0.546^{*} \\
(0.050)\end{array}$ & $\begin{array}{c}-0.556^{*} \\
(0.049)\end{array}$ & $\begin{array}{r}-0.555^{*} \\
(0.049)\end{array}$ & $\begin{array}{c}-0.555^{*} \\
(0.050)\end{array}$ \\
\hline$\gamma_{2}$ & $\begin{array}{c}-0.405^{*} \\
(0.048)\end{array}$ & $\begin{array}{c}-0.408^{*} \\
(0.043)\end{array}$ & $\begin{array}{l}-0.412^{*} \\
(0.043)\end{array}$ & $\begin{array}{c}-0.414^{*} \\
(0.043)\end{array}$ & $\begin{array}{c}-0.414^{*} \\
(0.043)\end{array}$ \\
\hline$\delta_{2}$ & $\begin{array}{l}-0.087 \\
(0.460)\end{array}$ & $\begin{array}{c}-0.091^{*} \\
(0.031)\end{array}$ & $\begin{array}{c}-0.097^{*} \\
(0.031)\end{array}$ & $\begin{array}{c}-0.097^{*} \\
(0.031)\end{array}$ & $\begin{array}{c}-0.096^{*} \\
(0.031)\end{array}$ \\
\hline Monday Morning & $\begin{array}{c}0.610^{*} \\
(0.167)\end{array}$ & $\begin{array}{c}0.523^{*} \\
(0.161)\end{array}$ & $\begin{array}{c}0.467^{*} \\
(0.156)\end{array}$ & $\begin{array}{c}0.468^{*} \\
(0.154)\end{array}$ & $\begin{array}{c}0.487^{*} \\
(0.162)\end{array}$ \\
\hline First Morning Trading & $\begin{array}{l}0.016 \\
(0.173)\end{array}$ & & & & \\
\hline First Afternoon Trading & $\begin{array}{c}0.603^{*} \\
(0.074)\end{array}$ & $\begin{array}{c}0.598^{*} \\
(0.072)\end{array}$ & $\begin{array}{c}0.602^{*} \\
(0.072)\end{array}$ & $\begin{array}{c}0.604^{*} \\
(0.071)\end{array}$ & $\begin{array}{c}0.604^{*} \\
(0.072)\end{array}$ \\
\hline After Holiday & $\begin{array}{l}0.068 \\
(0.100)\end{array}$ & & & & \\
\hline Tuesday & $\begin{array}{c}0.092 \\
(0.066)\end{array}$ & & & & \\
\hline Wednesday & $\begin{array}{l}0.144^{*} \\
(0.070)\end{array}$ & $\begin{array}{c}0.092 \\
(0.059)\end{array}$ & & & \\
\hline Thursday & $\begin{array}{l}0.154^{*} \\
(0.070)\end{array}$ & $\begin{array}{c}0.102 \\
(0.060)\end{array}$ & & & \\
\hline Friday & $\begin{array}{c}0.146^{*} \\
(0.069)\end{array}$ & $\begin{array}{c}0.094 \\
(0.060)\end{array}$ & & & \\
\hline \multicolumn{6}{|l|}{ U.S. } \\
\hline Employment Report & $\begin{array}{l}0.676^{*} \\
(0.314)\end{array}$ & $\begin{array}{c}0.694^{*} \\
(0.316)\end{array}$ & $\begin{array}{c}0.670^{*} \\
(0.275)\end{array}$ & $\begin{array}{c}0.750^{*} \\
(0.270)\end{array}$ & $\begin{array}{c}0.714^{*} \\
(0.298)\end{array}$ \\
\hline Producer Price Index & $\begin{array}{c}0.290 \\
(0.258)\end{array}$ & & & & \\
\hline Consumer Price Index & $\begin{array}{c}0.174 \\
(0.298)\end{array}$ & & & & \\
\hline FOMC meeting & $\begin{array}{c}0.424 \\
(0.310)\end{array}$ & & & & \\
\hline
\end{tabular}


Table 6: Thailand Intraday Volatility Regression (Continued)

\begin{tabular}{|c|c|c|c|c|c|}
\hline & Full System & Model I & Model II & GARCH & Std \\
\hline \multicolumn{6}{|l|}{$\underline{\text { JAPAN }}$} \\
\hline GDP & $\begin{array}{l}-0.645 \\
(0.745)\end{array}$ & & & & \\
\hline Industrial Production Index & $\begin{array}{l}-0.856 \\
(0.625)\end{array}$ & & & & \\
\hline Wholesale Price Index & $\begin{array}{l}0.079 \\
(0.301)\end{array}$ & & & & \\
\hline Tankan Survey & $\begin{array}{l}-1.149 \\
(0.592)\end{array}$ & & & & \\
\hline Monetary Policy Meeting & $\begin{array}{c}0.496 \\
(0.299)\end{array}$ & & & & \\
\hline \multicolumn{6}{|l|}{ KOREA } \\
\hline GDP & $\begin{array}{l}-0.870 \\
(0.625)\end{array}$ & & & & \\
\hline Industrial Production Index & $\begin{array}{c}0.541^{*} \\
(0.252)\end{array}$ & $\begin{array}{c}0.193 \\
(0.233)\end{array}$ & & & \\
\hline Consumer Price Index & $\begin{array}{l}-0.562 \\
(0.345)\end{array}$ & & & & \\
\hline Trade Balance & $\begin{array}{c}0.015 \\
(0.301)\end{array}$ & & & & \\
\hline \multicolumn{6}{|l|}{ THAILAND } \\
\hline GDP & $\begin{array}{l}-0.357 \\
(0.753)\end{array}$ & & & & \\
\hline Consumer Price Index & $\begin{array}{c}0.361 \\
(0.292)\end{array}$ & & & & \\
\hline Trade Balance & $\begin{array}{c}0.581^{*} \\
(0.228)\end{array}$ & $\begin{array}{c}0.547^{*} \\
(0.224)\end{array}$ & $\begin{array}{c}0.564^{*} \\
(0.216)\end{array}$ & $\begin{array}{c}0.543^{*} \\
(0.198)\end{array}$ & $\begin{array}{c}0.433 \\
(0.234)\end{array}$ \\
\hline \multicolumn{6}{|l|}{ ECONOMIC EVENTS } \\
\hline Thai Crisis & $\begin{array}{c}3.965^{*} \\
(0.318)\end{array}$ & $\begin{array}{c}3.949^{*} \\
(0.228)\end{array}$ & $\begin{array}{c}3.988^{*} \\
(0.222)\end{array}$ & $\begin{array}{c}3.274^{*} \\
(0.227)\end{array}$ & $\begin{array}{r}4.366^{*} \\
(0.219)\end{array}$ \\
\hline Korean Crisis & $\begin{array}{c}1.325^{*} \\
(0.238)\end{array}$ & $\begin{array}{c}1.255^{*} \\
(0.238)\end{array}$ & $\begin{array}{c}1.826^{*} \\
(0.239)\end{array}$ & $\begin{array}{c}0.203 \\
(0.276)\end{array}$ & $\begin{array}{c}1.242^{*} \\
(0.238)\end{array}$ \\
\hline Russian Crisis & $\begin{array}{c}4.451^{*} \\
(0.206)\end{array}$ & $\begin{array}{c}4.407^{*} \\
(0.201)\end{array}$ & $\begin{array}{c}4.354^{*} \\
(0.198)\end{array}$ & $\begin{array}{c}3.915^{*} \\
(0.181)\end{array}$ & $\begin{array}{c}4.848^{*} \\
(0.213)\end{array}$ \\
\hline & $\begin{array}{c}-0.540^{*} \\
(0.279)\end{array}$ & $\begin{array}{c}-0.568^{*} \\
(0.278)\end{array}$ & $\begin{array}{c}-0.589^{*} \\
(0.277)\end{array}$ & $\begin{array}{c}-0.781^{*} \\
(0.257)\end{array}$ & $\begin{array}{l}-0.372 \\
(0.277)\end{array}$ \\
\hline LTCM Crisis & $\begin{array}{c}4.189^{*} \\
(0.196)\end{array}$ & $\begin{array}{c}4.182^{*} \\
(0.195)\end{array}$ & $\begin{array}{c}4.212^{*} \\
(0.191)\end{array}$ & $\begin{array}{c}3.964^{*} \\
(0.181)\end{array}$ & $\begin{array}{c}4.347^{*} \\
(0.197)\end{array}$ \\
\hline
\end{tabular}


Table 6: Thailand Intraday Volatility Regression (Continued)

\begin{tabular}{cccccc}
\hline \hline & Full System & Model I & Model II & GARCH & Std \\
\hline & $0.666^{*}$ & $0.672^{*}$ & $0.697^{*}$ & $0.591^{*}$ & $0.748^{*}$ \\
& $(0.186)$ & $(0.185)$ & $(0.185)$ & $(0.179)$ & $(0.188)$ \\
Brazilian Crisis & & & & \\
& $2.842^{*}$ & $2.845^{*}$ & $2.874^{*}$ & $2.438^{*}$ & $2.966^{*}$ \\
& $(0.105)$ & $(0.105)$ & $(0.098)$ & $(0.087)$ & $(0.102)$ \\
& $-0.383^{*}$ & $-0.389^{*}$ & $-0.375^{*}$ & $-0.559^{*}$ & $-0.336^{*}$ \\
& $(0.088)$ & $(0.087)$ & $(0.087)$ & $(0.087)$ & $(0.087)$ \\
\hline \hline
\end{tabular}

The table shows estimates of intraday volatility regression for Thailand. Newey and West (1987) robust standard errors with 20 lags correction are in parentheses. The symbol * indicates the estimate is significant at the $95 \%$ confidence interval. Details on dynamic response are in Appendix B. 
Table 7: Impact of Information on Intraday Volume

\begin{tabular}{|c|c|c|}
\hline & Korea & Thailand \\
\hline Intercept & $\begin{array}{c}0.594^{*} \\
(0.113)\end{array}$ & $\begin{array}{c}0.301 \\
(0.156)\end{array}$ \\
\hline$\mu_{1}$ & $\begin{array}{c}-0.299^{*} \\
(0.036)\end{array}$ & $\begin{array}{c}-0.312^{*} \\
(0.042)\end{array}$ \\
\hline$\mu_{2}$ & $\begin{array}{l}0.020^{*} \\
(0.002)\end{array}$ & $\begin{array}{c}0.019^{*} \\
(0.002)\end{array}$ \\
\hline$\gamma_{1}$ & $\begin{array}{c}-0.310^{*} \\
(0.050)\end{array}$ & $\begin{array}{c}-0.249^{*} \\
(0.063)\end{array}$ \\
\hline$\delta_{1}$ & $\begin{array}{c}0.105^{*} \\
(0.014)\end{array}$ & $\begin{array}{l}0.155^{*} \\
(0.025)\end{array}$ \\
\hline$\gamma_{2}$ & $\begin{array}{c}-0.053^{*} \\
(0.011)\end{array}$ & $\begin{array}{r}-0.108^{*} \\
(0.013)\end{array}$ \\
\hline$\delta_{2}$ & $\begin{array}{c}0.009 \\
(0.006)\end{array}$ & $\begin{array}{c}0.114^{*} \\
(0.010)\end{array}$ \\
\hline$\gamma_{3}$ & & $\begin{array}{c}0.032^{*} \\
(0.006)\end{array}$ \\
\hline$\delta_{3}$ & & $\begin{array}{c}0.077^{*} \\
(0.006)\end{array}$ \\
\hline Monday Morning & & $\begin{array}{c}0.112^{*} \\
(0.041)\end{array}$ \\
\hline First Morning Trading & $\begin{array}{c}0.341^{*} \\
(0.205)\end{array}$ & $\begin{array}{l}0.166^{*} \\
(0.033)\end{array}$ \\
\hline First Afternoon Trading & $\begin{array}{c}0.363^{*} \\
(0.008)\end{array}$ & $\begin{array}{c}0.192^{*} \\
(0.014)\end{array}$ \\
\hline Last Trading & $\begin{array}{c}-1.223^{*} \\
(0.021)\end{array}$ & \\
\hline After Holiday & & $\begin{array}{l}0.107^{*} \\
(0.035)\end{array}$ \\
\hline Tuesday & $\begin{array}{c}0.075^{*} \\
(0.018)\end{array}$ & $\begin{array}{l}0.202^{*} \\
(0.026)\end{array}$ \\
\hline Wednesday & $\begin{array}{c}0.133^{*} \\
(0.019)\end{array}$ & $\begin{array}{c}0.291 \\
(0.027)\end{array}$ \\
\hline Thursday & $\begin{array}{c}0.128^{*} \\
(0.018)\end{array}$ & $\begin{array}{c}0.264 \\
(0.026)\end{array}$ \\
\hline Friday & $\begin{array}{c}0.060^{*} \\
(0.020)\end{array}$ & $\begin{array}{c}0.231^{*} \\
(0.028)\end{array}$ \\
\hline \multicolumn{3}{|l|}{ U.S. } \\
\hline Employment Report & & $\begin{array}{c}0.195^{*} \\
(0.078)\end{array}$ \\
\hline Producer Price Index & & \\
\hline
\end{tabular}


Table 7: Impact of Information on Intraday Volume (Continued)

\begin{tabular}{|c|c|c|}
\hline & Korea & Thailand \\
\hline \multicolumn{3}{|l|}{ Consumer Price Index } \\
\hline \multicolumn{3}{|l|}{ FOMC } \\
\hline \multicolumn{3}{|l|}{ JAPAN } \\
\hline \multicolumn{3}{|l|}{ GDP } \\
\hline \multicolumn{3}{|l|}{ Industrial Production Index } \\
\hline \multicolumn{3}{|l|}{ Wholesale Price Index } \\
\hline \multicolumn{3}{|l|}{ Tankan Survey } \\
\hline Monetary Policy Meeting & $\begin{array}{c}0.224^{*} \\
(0.100)\end{array}$ & \\
\hline \multicolumn{3}{|l|}{ KOREA } \\
\hline \multicolumn{3}{|l|}{ GDP } \\
\hline \multicolumn{3}{|l|}{ Industrial Production Index } \\
\hline \multicolumn{3}{|l|}{ Consumer Price Index } \\
\hline Trade Balance & & \\
\hline THAILAND & & \\
\hline
\end{tabular}

GDP

Consumer Price Index

Trade Balance

ECONOMIC EVENTS

\begin{tabular}{lcc} 
Thai Crisis & $0.649^{*}$ & $0.973^{*}$ \\
& $(0.021)$ & $(0.035)$ \\
& & $0.090^{*}$ \\
& & $(0.012)$ \\
Korean Crisis & & \\
& $0.159^{*}$ & $-0.233^{*}$ \\
& $(0.030)$ & $(0.067)$ \\
& $0.391^{*}$ \\
& \\
\hline
\end{tabular}


Table 7: Impact of Information on Intraday Volume (Continued)

\begin{tabular}{lcc}
\hline \hline & Korea & Thailand \\
\hline \multirow{2}{*}{ Russian Crisis } & $0.641^{*}$ & $1.670^{*}$ \\
& $(0.022)$ & $(0.024)$ \\
& & $-0.789^{*}$ \\
& & $(0.027)$ \\
LTCM Crisis & $0.650^{*}$ & $1.199^{*}$ \\
& $(0.028)$ & $(0.115)$ \\
& & $0.129^{*}$ \\
Brazilian Crisis & & $(0.046)$ \\
& & $1.146^{*}$ \\
& & $(0.021)$ \\
& & $-0.431^{*}$ \\
& & $(0.016)$ \\
\hline \hline
\end{tabular}

The table shows estimates of intraday volume regression of Korea Subsample I and Thailand. Newey and West (1987) robust standard errors with 18 lags correction are in parentheses. The symbol * indicates the estimate is significant at the $95 \%$ confidence interval. Details on dynamic response are in Appendix B. 


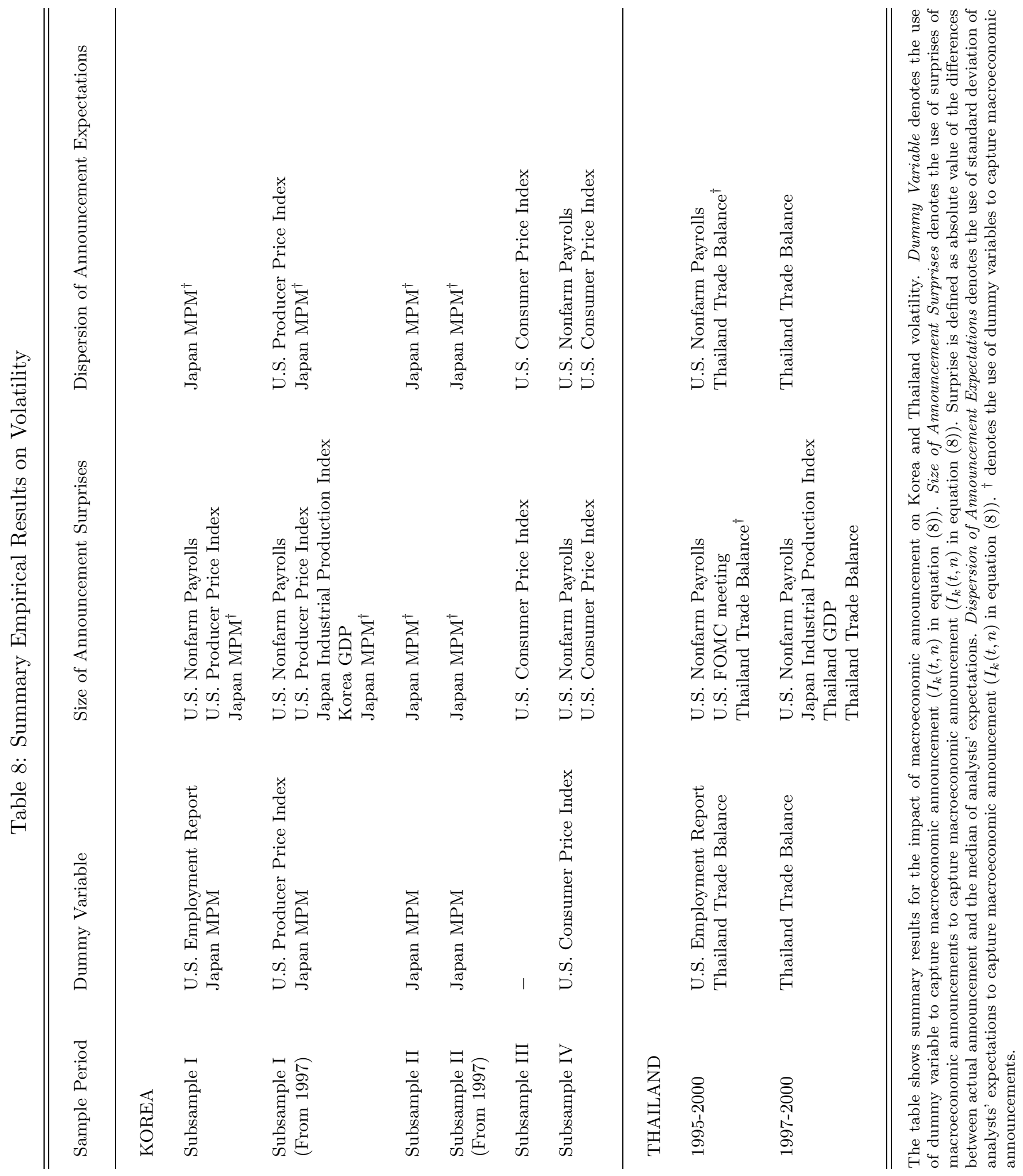




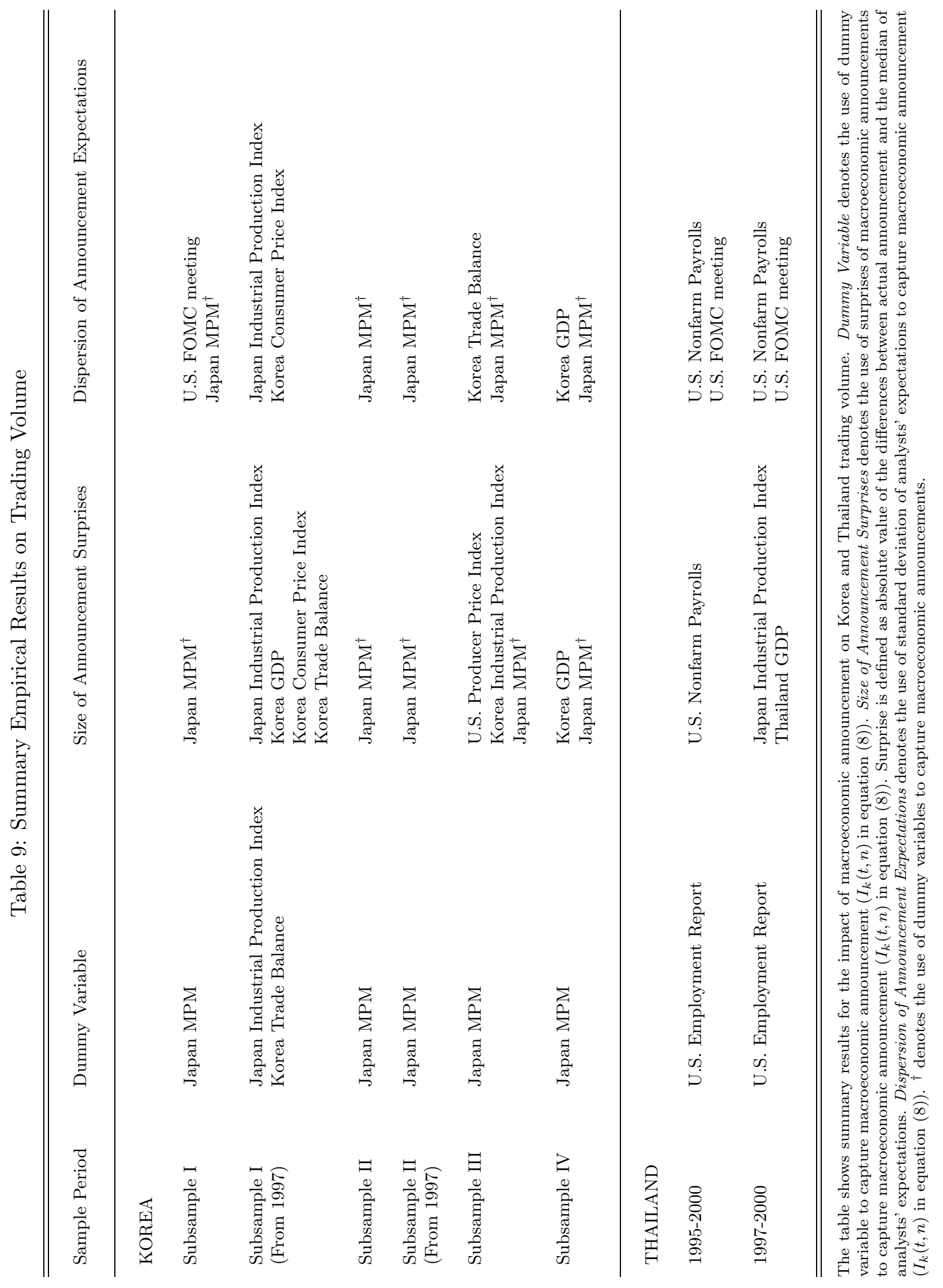




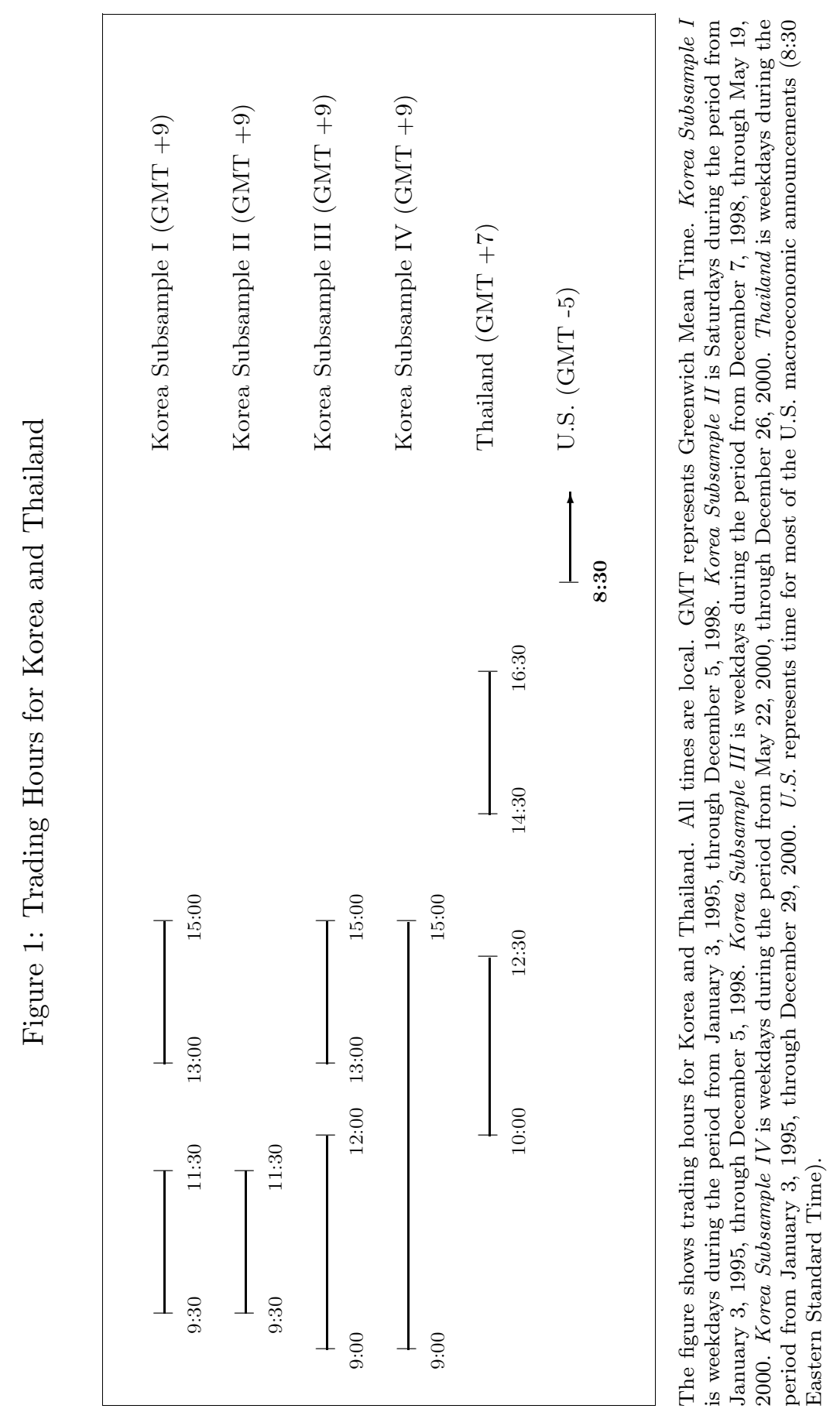


Figure 2: Korea (Subsample I) Intraday Return, Absolute Return Deviation, and Volume
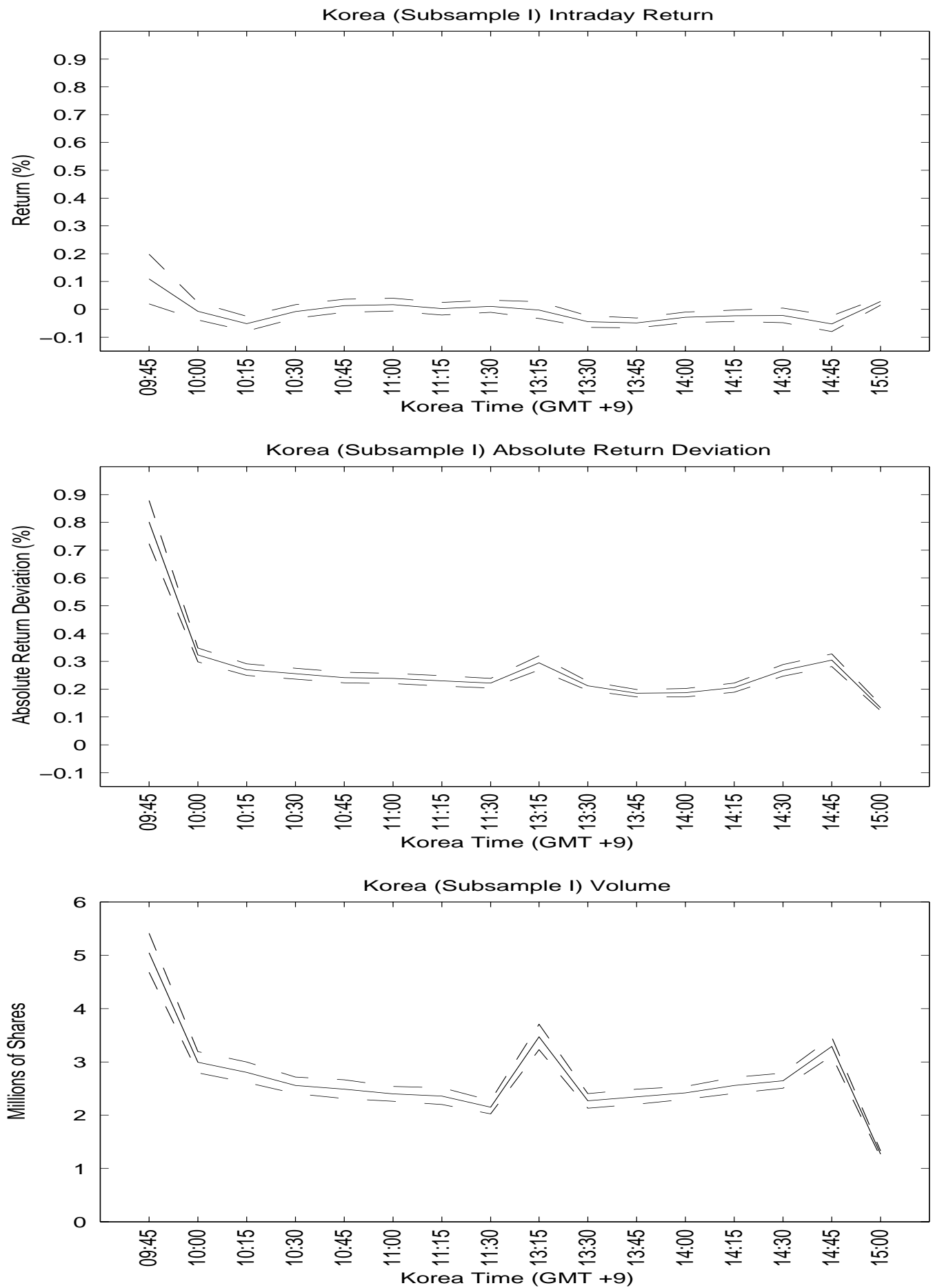

The figures show averages of the fifteen-minute intraday pattern of return, absolute return deviation (volatility), and volume. All times are in Korean local time $(\mathrm{GMT}+9)$. The dashed line represents a two-standard deviations band. The averages and standard deviations are computed jointly from GMM with Newey and West (1987) standard errors. 
Figure 3: Thailand Intraday Return, Absolute Return Deviation, and Volume
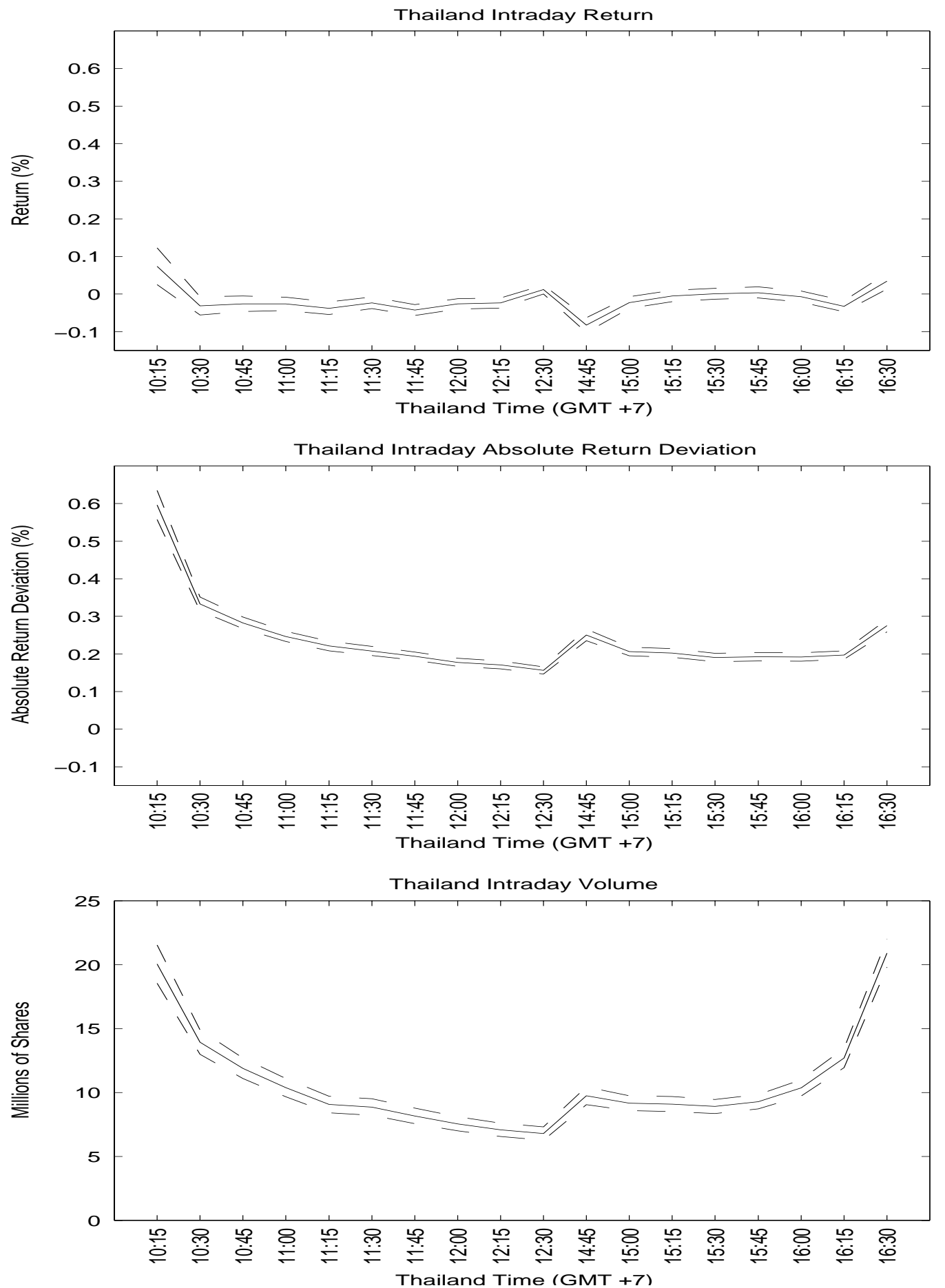

The figures show averages of the fifteen-minute intraday pattern of return, absolute return deviation (volatility), and volume. All times are in Thai local time $(\mathrm{GMT}+7)$. The dashed line represents a two-standard deviations band. The averages and standard deviations are computed jointly from GMM with Newey and West (1987) standard errors. 
Figure 4: Number of Macroeconomic Announcements
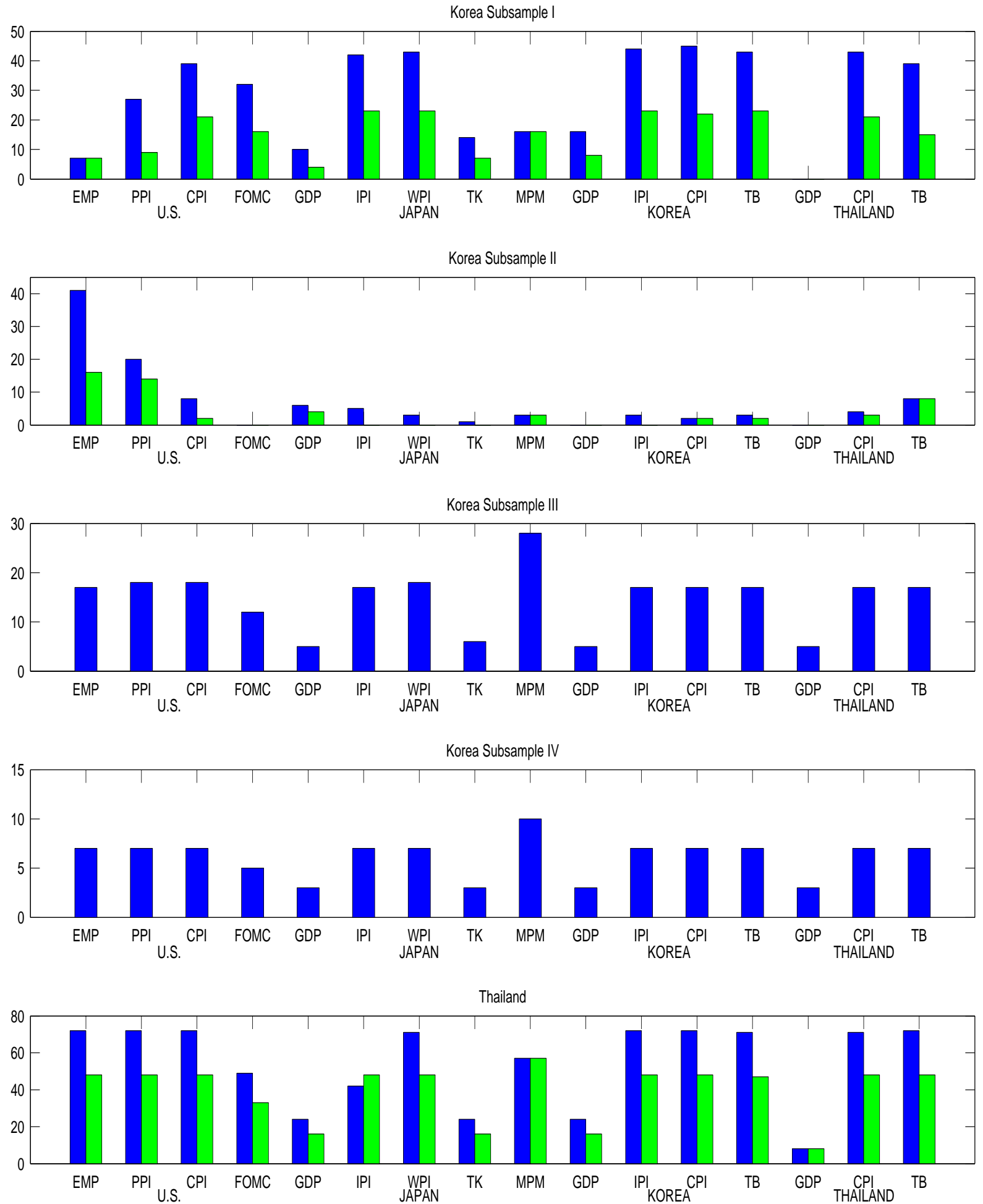

The figure shows the number of macroeconomic announcements in Korea and Thailand. The black bars show the full sample for each subsample. The grey bars show the sample in each subsample from 1997. 
Figure 5: Impacts of the U.S. Employment Report on Korean Equity Market

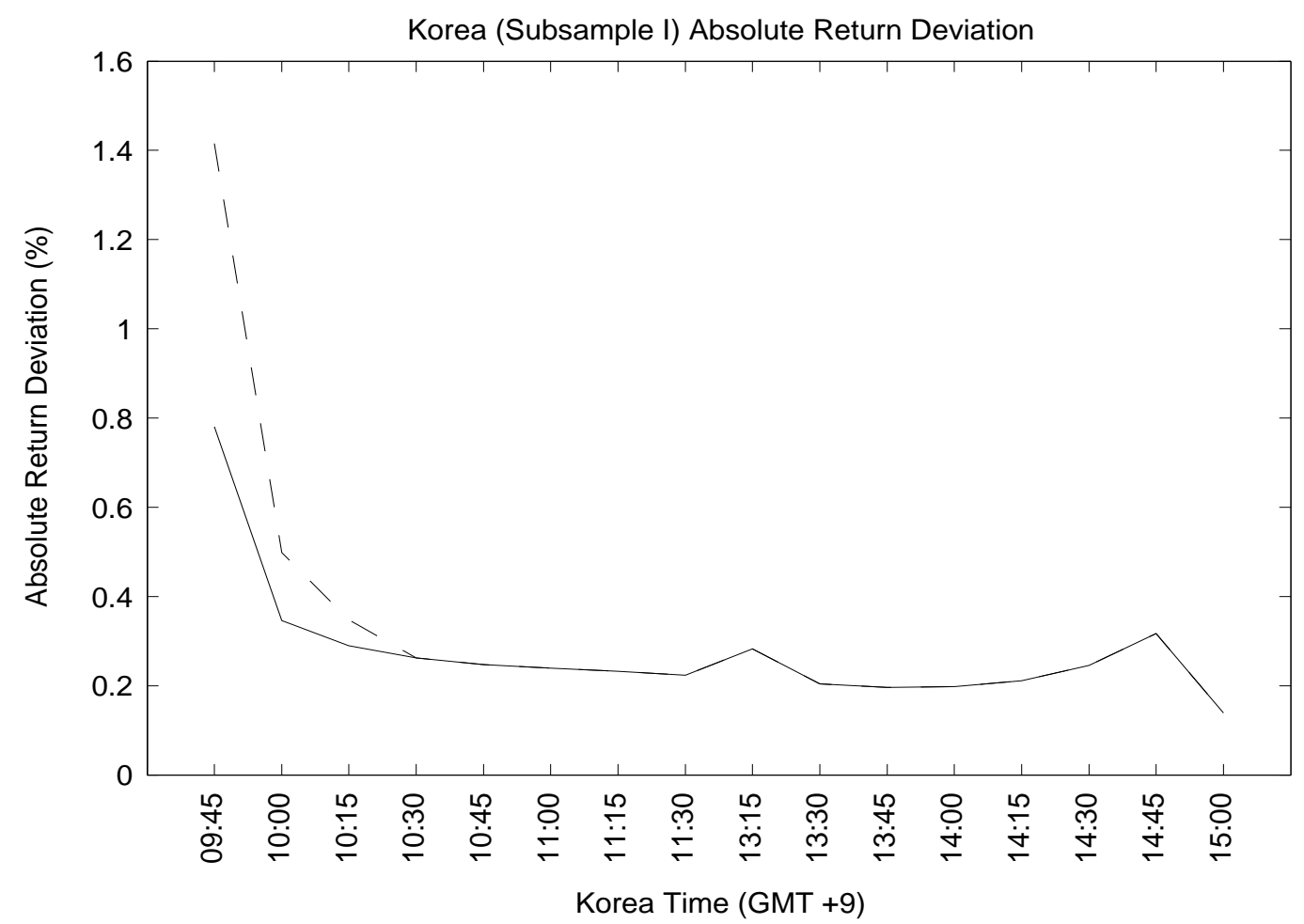

The figure shows impact of the U.S. Employment Report on Korean return volatility. The solid line shows the averages of the fitted intraday volatility. The dashed line shows the averages of the fitted intraday volatility on the days with the announcements. 
Figure 6: Impacts of the U.S. Employment Report on Thai Equity Market
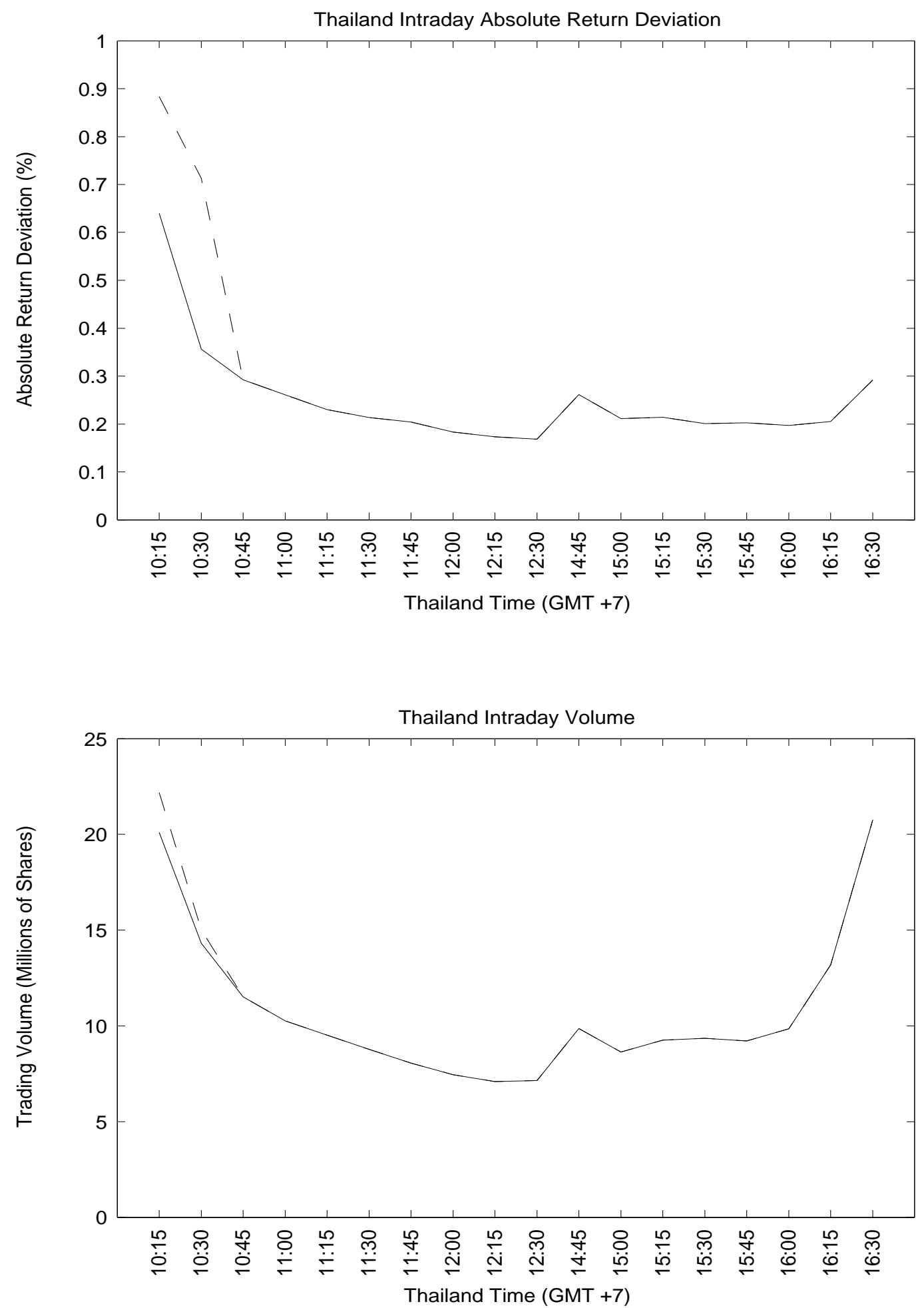

The figure shows impact of the U.S. Employment Report on Thai return volatility (trading volume). The solid line shows the averages of the fitted intraday volatility (trading volume). The dashed line shows the averages of the fitted intraday volatility on the days with the announcements (trading volume). 
Figure 7: Impacts of Thai Trade Balance on Thai Equity Market

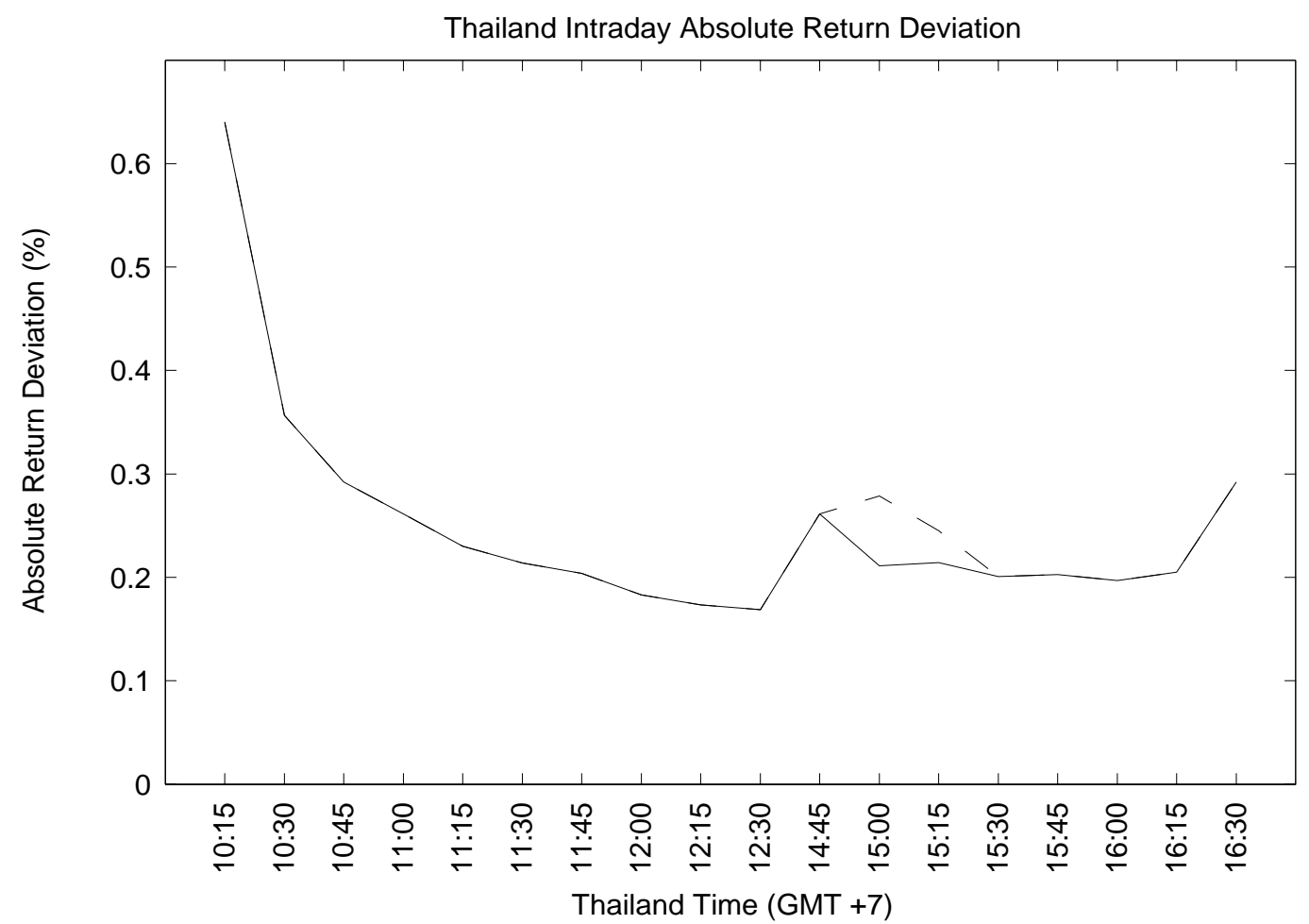

The figure shows impact of Thai Trade Balance on Thai return volatility. The solid line shows the averages of the fitted intraday volatility. The dashed line shows the averages of the fitted intraday volatility on the days with the announcements. 
Figure 8: Average Intraday Absolute Return (Volatility) Fit
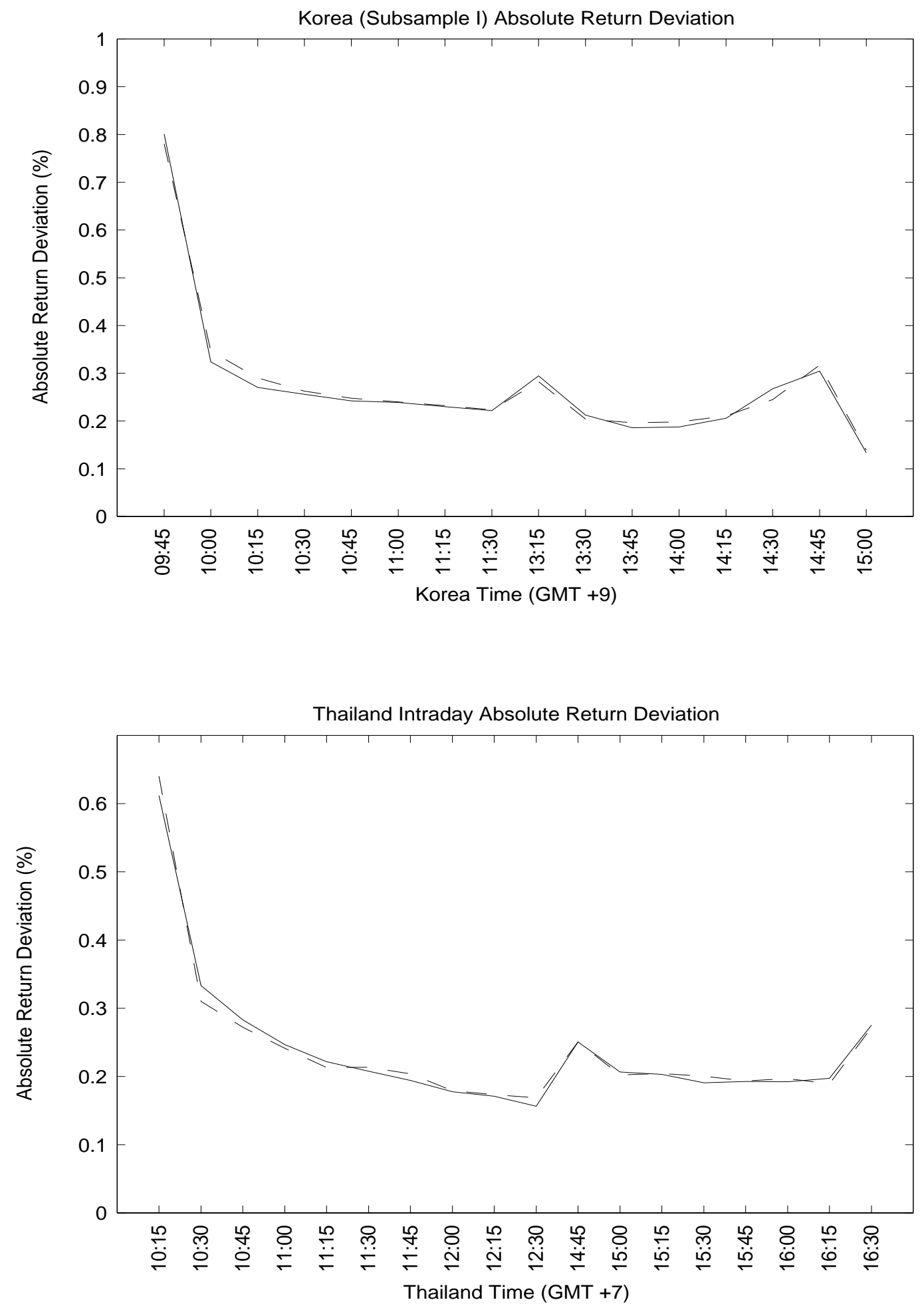

The figure shows averages of the intraday volatility (solid line) with the averages of the fitted intraday volatility (dashed line). 
Figure 9: Average Intraday Volume Fit
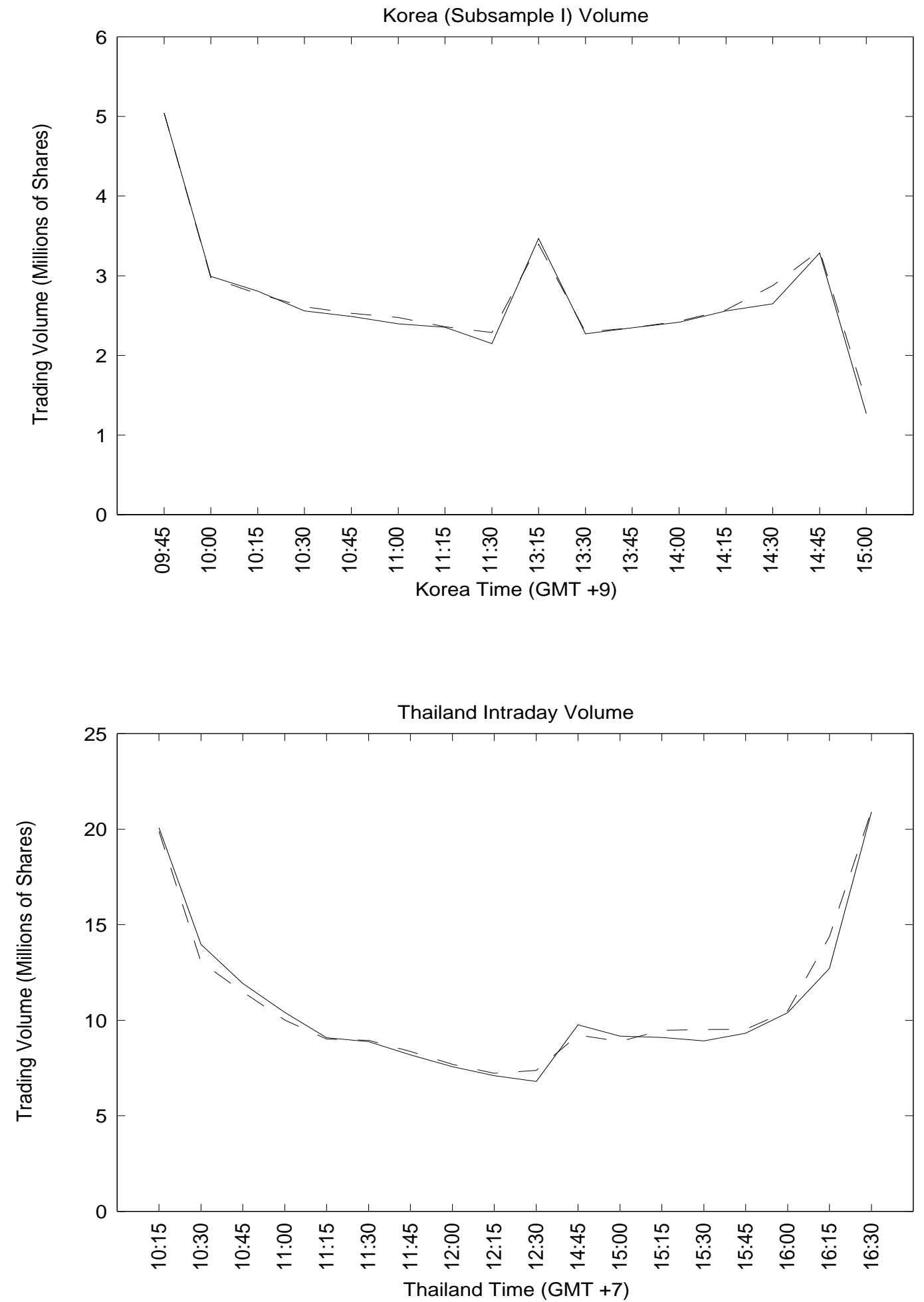

The figure shows averages of the intraday volume (solid line) with the averages of the fitted intrady volume (dashed line). 